\title{
ILLUSTRATING SWING VOTES I: INDIANA SUPREME COURT
}

\author{
NiCHOLAS L. GEORGAKOPOULOS AND FRANK SULLIVAN, JR.*
}

\section{INTRODUCTION}

Could a graph display the ways that tight coalitions form on a supreme court? Wouldn't it be interesting to juxtapose the corresponding arrangement of the justices in one subject matter, such as tort, to a different one, such as criminal procedure? We propose such a method of illustrating tight splits that also reveals all swing votes.

In this article, we develop a method for illustrating graphically (a) the majorities that issue tightly split opinions; (b) the swing votes between the different majorities; and (c) the opinions those majorities issue. ${ }^{1}$ We develop this method in the setting of the five-member Indiana Supreme Court as it was constituted between 1999 and 2010 using its composition as defined by its junior justice being Justice Robert D. Rucker. ${ }^{2}$ The other members of the court were Chief Justice Randall T. Shepard and Justices Brent E. Dickson, Frank Sullivan, Jr. (an author of this article), and Theodore R. Boehm. As the court's membership did not change during that nearly eleven-year period, there were a substantial number-176-tightly split decisions. We examine them and observe many swing votes, varied coalitions, and differentiation by opinion subject matter. We develop graphical techniques to illustrate those different tendencies.

The principal contribution of this article is in laying the groundwork for visualizing and analyzing voluminous tightly split opinions, the majorities that produce them, and the corresponding swing votes. We posit that the placement of the majorities in a circle is more instructive than their placement in a parliament-like semicircle, which produces artificial extremes that are absent from the data. In the same context, we also develop tools to identify visually different alignments of a supreme court's justices in different legal subject

* Nicholas Georgakopoulos is the Harold R. Woodard Professor of Law, Indiana University Robert H. McKinney School of Law, Indianapolis. Frank Sullivan, Jr., is the Indiana University Bicentennial Professor at the same institution and was an Associate Justice of the Indiana Supreme Court from 1993 until 2012. We wish to thank Jim Chen, Kent Greenfield, Shi-Ling Hsu, Jonathan Nash, Richard Posner for their comments as well as participants in the 2016 Midwestern Law and Economics Association and acknowledge the excellent research assistance of Allan Griffey. Send your comments to us at ngeorgak@iu.edu.

1. This article builds on previously published work analyzing the judicial coalitions that formed in tightly split decisions of the United States and Indiana Supreme Courts - the 5-4 and 3-2 opinions issued by those respective courts. Frank Sullivan, Jr., Nicholas L. Georgakopoulos, \& Dimitri Georgakopoulos, The Fluidity of Judicial Coalitions: A Surprising Look at Coalitions within the Supreme Courts of the United States and Indiana, JudiCATURE, Autumn 2016, at 34, 36.

2. This follows our earlier approach of defining a particular court by using the time period during which the composition of the court is unchanged. This approach is explained in further detail in Sullivan, Jr., Georgakopoulos, \& Georgakopoulos, supra note 1, at 36. 
matters (i.e., topics or areas of law). We note that this resulting image of adjudication is markedly unlike what would appear if the median voter theorem applied.

We are not aware of any prior attempt to visualize voluminous supreme court data besides illustrations of the ideological position of justices. ${ }^{3}$ By contrast, many have identified swing votes with even scientific rigor and many have tried to identify differential attitudes of the United States Supreme Court by legal subject matter. Out of a vast expanse of literature, some milestones may be Andrew D. Martin, Kevin M. Quinn, and Lee Epstein, The Median Justice on the United States Supreme Court, 83 N.C.L. REV. 1275 (2005) (studying the voting of Justice O'Connor as the median justice) and Mark Klock, Cooperation and Division: An Empirical Analysis of Voting Similarities and Differences During the Stable Rehnquist Court Era-1994 to 2005, 22 CORNELL J.L. \& PUB. POL'Y 537 (2013) (studying details of what we term the Breyer composition). Others study the voting of justices on specific subject matters, for example, Lewis M. Wasserman and James C. Hardy, U.S. Supreme Court Justices' Religious and Party Affiliation, Case-Level Factors, Decisional Era and Voting in Establishment Clause Disputes Involving Public Education: 1947-2012, 2 BRIT. J. AM. LEGAL STUD. 111 (2013) (studying the votes about the establishment clause in school finance cases). Others have studied the effect of unexpected features of the system, such as the bias of the Republican Party toward appointing younger justices, Jonathan N. Katz and Matthew L. Spitzer, What's Age Got to Do with It? Supreme Court Appointees and the Long Run Location of the Supreme Court Median Justice, 46 ARIZ. ST. L.J. 41 (2014) (with a detailed discussion of the median justice theory and variations of it; supporting eighteenyear staggered terms for justices). One research method examines all coalitions to identify the median justice, Paul H. Edelman and Jim Chen, The Most Dangerous Justice: The Supreme Court at the Bar of Mathematics, 70 S. CAL. L. REV. 63 (1996). Our approach stands in contrast to attempts to identify a single justice as the swing vote because (a) we reveal all the swing votes; and (b) several swing votes are visibly material.

\section{VISUALIZING THE INDIANA DATA (1999-2010)}

Visualizing swing votes requires locating the output of the majorities connected by that swing vote. For example, consider two tight majorities of the five-member Indiana Supreme Court we study, that of Boehm-Rucker-Sullivan and that of Shepard-Boehm-Dickson. The swing vote connecting them is that of

3. The two illustrations of ideological positions of justices that stand out are from Martin \& Quinn and Bailey, with additional such graphics in other publications by Bailey. See Andrew D. Martin \& Kevin M. Quinn, Dynamic Ideal Point Estimation via Markov Chain Monte Carlo for the U.S. Supreme Court, 1953-1999, 10 Pol. AnAL. 134 (2002); Michael A. Bailey, Measuring Court Preferences, 1950-2011: Agendas, Polarity and Heterogeneity (Working Paper, August 2012). See also Wikipedia, Ideological Leanings of U.S. Supreme Court Justices (as of Sept. 28, 2017) [https://perma.cc/7LCZ-K6HM]. 
Boehm. To display Boehm's swing vote, we must place the two majorities that it connects. Majorities that do not correspond to tight splits we consider irrelevant, because the majority needs to lose more than one vote for a swing to materialize in the outcome.

A swing vote may be motivated by a myriad of concerns. Deducing these is part of what makes the examination of swing votes interesting. We cannot impose a structure a priori; that structure must arise from the data if it exists. Nevertheless, a gauge is necessary to guide the placement of the majorities. In view of the dominant political division between right and left ("political slant" in our parlance), we start with that as our gauge. Rather than obscuring other motivations of swing votes, we find that using this gauge to arrange the majorities reveals additional motivations for swing votes. Political slant is also convenient because nearly all issues translate to political positions. Motivations unrelated to political concerns surely exist, but we do not think that locating the majorities by political slant obscures them. For example, although textualism has recently been associated with the right, left-wing textualists exist, such as Professor Akhil Amar. Thus, the concern, for example, would be that justices who are textualists and lean left may ally themselves due to textualism with textualists who lean right. Because we enter the substance of the opinions of coalitions, we do observe such instances of coalitions formed for unrelated reasons. ${ }^{4}$

That we use political slant to arrange the majorities does not mean that a court should look like a legislature, with the far right seen as the polar opposite of the far left. Rather, the arrangement should enable coalitions motivated by similar reasons formed by justices of opposing political ideology to appear.

A well-known criminal law decision of the United States Supreme Court provides an example. In Apprendi v. New Jersey (a case recognizing a right to a jury determination of any fact that increases a penalty above the statutory

4. An Indiana example may be found in attitudes toward appellate review of criminal sentences. Unlike some members of the court who considered appellate review of sentences to impinge upon the prerogative of the court of first instance, e.g., Frye v. State, 837 N.E.2d 1012, 1015 (Ind. 2005) (Dickson, J., dissenting), and Scheckel v. State, 655 N.E.2d 506, 511 (Ind. 1995) (Dickson, J., dissenting), Shepard (appointed by a Republican governor) and Sullivan (appointed by a Democratic governor) were both open to such requests for review but each articulated a different justification for being so. Shepard was of the view that too high a barrier to appellate review of sentences runs "the risk of impinging on another constitutional right contained in Article 7, that the Supreme Court's rules shall 'provide in all cases an absolute right to one appeal.' Serino v. State, 798 N.E.2d 852, 856 (Ind. 2003) (quoting IND. CONST. art. VII, § 6). Sullivan looked to the fact that the same constitutional amendment that authorized appellate judges to review and revise sentences was the constitutional amendment that insulated appellate judges from partisan elections and concluded that the review and revise authority is intended, at least in part, to temper decisions of trial judges whose decisions are sometimes reviewed at the ballot box. Frank Sullivan, Jr., Selected Developments in Indiana Criminal Sentencing and Death Penalty Law (1993-2012), 49 IND. L. REV. 1349, 1362 (2016). 
maximum), ${ }^{5}$ the five-justice majority consisted of liberals Stevens, Souter, and Ginsburg and conservatives Scalia and Thomas. Placing the Apprendi coalition in a circle makes more sense than placing it in a parliamentary semicircle. The circular placement of the coalitions preserves the principle that swing votes connect opposing views on different grounds. We try to make swing votes appear as close to the diameter of the circle as possible, whereas in a parliamentary arrangement of the majorities, although some swing votes would connect opposing ends of the spectrum, others would connect apparently centrist factions. We feel that this would obscure differences in the latter cases. ${ }^{6}$

We recognize that the assignment of political slant may be debatable, inconclusive, and, occasionally, a gross oversimplification. Nevertheless, it illuminates the graphs and the analysis. Reasonable people might disagree on a few percentage points of assignment of political slant. Still, the assignment of a slant for the vast majority of opinions is uncontested. Our assignment of slants should be taken with this caveat. However, even if a reader were to disagree with even 5 percent of our slant assignments, the essence of the graphs and the dynamics they reveal remain unchanged.

Guided by political slant, we produce the figure for the Indiana court essentially deterministically. We place the most conservative coalition on the farthest right of the circle, at the three o'clock position, and the most liberal coalition of the farthest left, at the nine o'clock position. We place the next most liberal above the previously placed one, and then below it, while preserving opposition in swing votes. Vice-versa, the next most conservative coalition we place below the most conservative one. Appendix A explains the process in detail.

We illustrate each opinion as an extension of a narrow central angle or thick radius of the circle of the majorities - akin to a very thin slice of a large donutshaped pizza. As the majority that issues the greatest number of opinions issues thirty-five opinions, the one-tenth segment of the circle that corresponds to each majority divided by thirty-five produces the arc, the space to which each opinion can correspond. We illustrate conservative opinions as dark gray (or red in the online version) and liberal opinions in hexagonal shading (or blue in the online version), separated by black lines on the outside of the circle. ${ }^{7}$ For example, the Shepard-Dickson-Rucker majority that appears at the two-o'clock position

5. Apprendi v. New Jersey, 530 U.S. 466 (2000).

6. A vivid example of this is in the separation of sentencing from tort opinions of the Indiana court. If we had used a semicircular parliamentary figure, then one of the two would appear to be more a dispute between extremes than the other. This is obviously false. Rather, the court separated itself about tort issues in a different way than it separated itself about sentencing issues. Neither contrast is greater than the other. Rather, they are different, but important, contrasts that the circular arrangement preserves, whereas a parliamentary arrangement would subordinate one.

7. By using red for conservative and blue for liberal, we follow the practice of the Republican and Democratic parties in the United States, which is the opposite to much of the world, with the UK, e.g., having Labour use red and the Conservatives use blue. We lighten both the red and blue hues for readability. 
issued two liberal opinions and seven conservative ones. Because the liberal side of the circle is toward the left, the nine o'clock position, we gather each majority's liberal opinions on the left side. The result is figure 1 .

The liberal opinions are fifty, exactly one-third of the 150. Appendix B has tables with all the opinions per majority, our one-sentence summary of majority and dissent, and our coding of each opinion in a legal subject matter and as liberal or conservative.

By virtue of placing the next most liberal majority above the most liberal one and the next most conservative below the most conservative one, the figure has a slight clockwise bias compared to an ideal where the majorities adjacent to the extremes are equally less extreme or to other arrangements. ${ }^{8}$ Nevertheless, we draw comfort that the resulting illustration shows that this arrangement is quite accurate a sorting of the majorities from conservative to liberal. Generally, moving from the conservative three o'clock position toward the liberal nine o'clock position, either counterclockwise from above or clockwise from below, increases the proportion of liberal opinions.

8. An alternative approach would be to place the next most extreme majority above the most extreme one on both sides of the circle. This would not produce by design the bias, but it would erode the oppositional nature of the graph. By contrast, the method that we use preserves opposition by having the next most extreme majorities on opposite sides of the circle (rather than at the two o'clock and ten o'clock positions that would result from placing them above the extremes). 


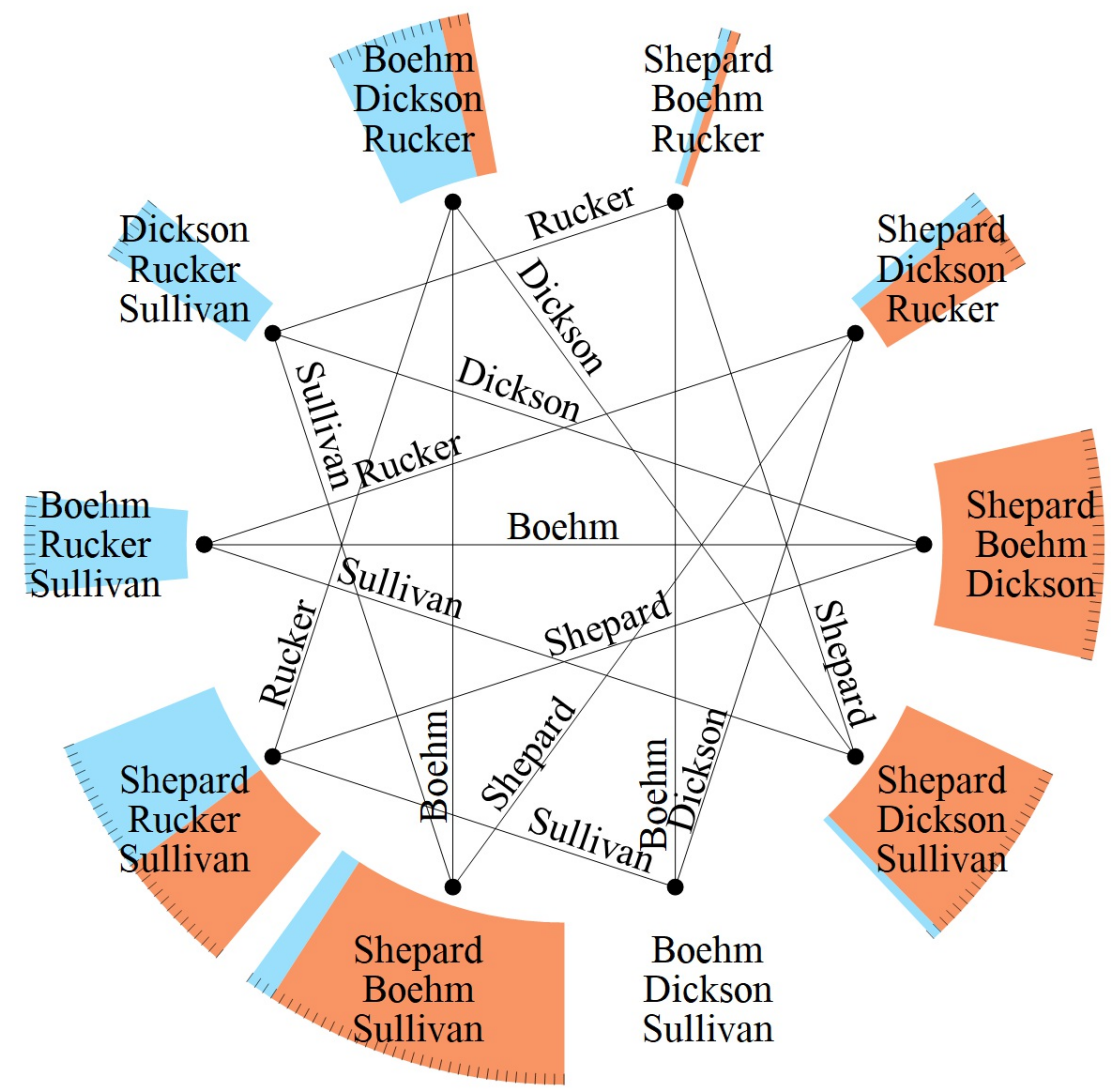

Figure 1. The swing votes and the 150 opinions, conservative (dark gray or red in the online version) and liberal (hexagonal shading or blue in the online version), placed at their majorities.

We also draw confidence in this approach because each majority shares two justices with each of its neighbors. Thus, judicial outlook should tend to change gradually. This is an important advantage of the circular representation of the majorities that would be lost in other arrangements, such as a parliamentary layout in a semicircle. A five-member court that has three-member majorities in tightly split opinions would be the largest that can be represented in a circle retaining this feature of gradual change by one justice at a time. ${ }^{9}$

The absence of dominant swing votes is apparent in figure 1 . In contrast to

9. In the subsequent article of this series, we find no composition of the United States Supreme Court that provides sufficient data for a similarly deterministic placement of its majorities. If a nine-member or a seven-member supreme court did provide enough data, the proper representation of its majorities that would retain their gradually changing nature may be possible in more dimensions. 
the dominant swing vote of Kennedy in recent compositions of the United States Supreme Court, no swing votes tend to predominate. This first approach to these opinions reveals a court that aligns itself in many majorities to issue tightly split opinions. In a prior publication, we calculated an index of the fluidity of a court's coalitions, where this court did indeed produce a high index of fluidity, which is consistent with what we observe here. ${ }^{10}$

\section{CENTERS OF GRAVITY}

Consider the difference of a court that issues mixed liberal and conservative opinions from various majorities, as does this composition of the Indiana Supreme Court, from a court with a single dominant swing vote. Weighted centers of gravity of liberal and conservative opinions produce a visualization of this difference. If all the liberal opinions came from one majority, say at nine o'clock, then the center of gravity of the liberal opinions would be that nine o'clock point. As the majorities that are sources of liberal opinions spread around the circle, the weights of the opinions at those corresponding points join the calculation of the center of gravity and move it toward the center of the circle.

\section{A. All Opinions}

The centers of gravity of the liberal and the conservative opinions are quite far from any specific majorities. Figure 2 illustrates the centers of gravity, liberal and conservative, of all tightly split opinions. The figure draws a heavy line that connects the conservative and liberal centers of gravity. Whereas in a court with a single dominant swing vote, that line would track the line that corresponds to that swing vote, in this court this line is much closer to connecting points that are about in the middle of each semicircle. Also, the relatively frequent formation of the majorities at seven and eight o'clock, Shepard-Boehm-Sullivan and Shepard-Rucker-Sullivan, pull the line a little in that direction rather than the line appearing at the center of the graph.

We do not propose a theory about where the ideal line that connects the centers of gravity of a court should be; this depends on one's views about how gradually the change from conservative to liberal opinions coming from each majority should occur and the ideal composition of the extremes at nine and three o'clock, including whether they should not produce opinions of only one political slant. If the three o'clock majority produced a few more conservative opinions than the nine o'clock majority, and the proportion increased gradually and equally along both the top and the bottom parts of the circle, then the line connecting those centers of gravity should be fairly short, in the center of the graph, and almost horizontal. We actually observe a variation of this hypothesis when we focus on the other opinions (i.e., not tort; not criminal procedure; and not sentencing, professional responsibility, nor criminal law opinions) in figure 6, where we see a very short line connecting the centers of gravity.

10. Sullivan, Georgakopoulos \& Georgakopoulos, supra note 1, at 36 . 
If the mix of opinions at the extreme opposites, at nine and three o'clock, were of only one slant but the intermediate majorities produced gradually changing mixes of liberal and conservative opinions, then the ends of the line should be at about the center of each semicircle. The two small points on the central line of the figure, the line of Boehm as the central swing vote, illustrate the ends of such a line. ${ }^{11}$

Our knowledge of the details of the opinions enables us to focus on subsets of opinions, perhaps revealing a more precise alignment of the justices by subject matter. We observe three broad categories and a fourth residual category. Broadly speaking, the three categories regard tort, criminal procedure, and sentencing.

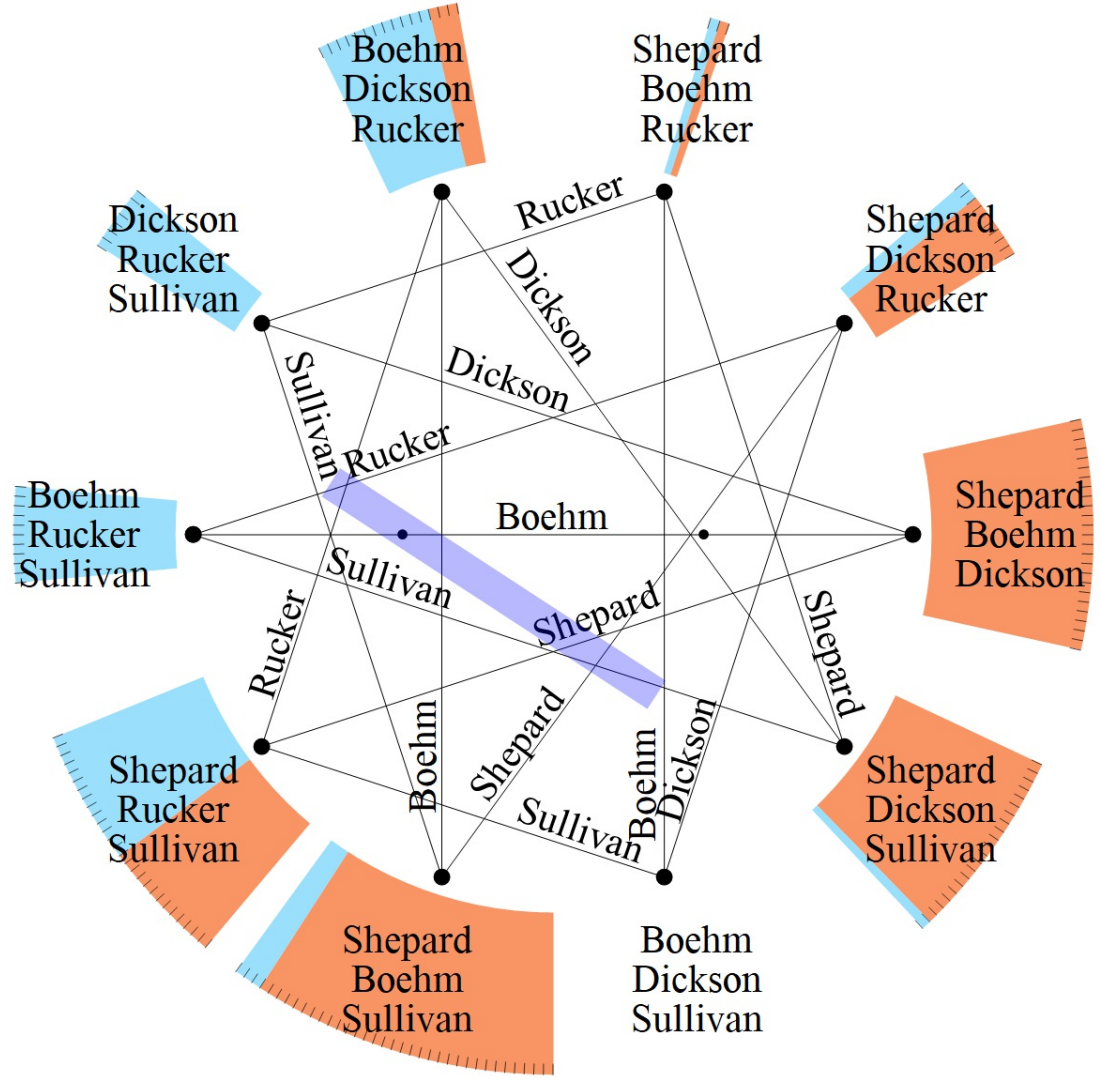

Figure 2. The opinions with a heavy line connecting the liberal and conservative centers of gravity.

11. The assumptions that produce those points are that the mix of each type of opinion, liberal or conservative, increases by 20 percent with each majority, going from 100 percent to zero at the two opposite sides of the graph. 


\section{B. The Tort Opinions}

Although Criminal Procedure seems extremely well represented in this sample of opinions, the largest number of opinions comes from a subset about liability between private entities, what we characterize (without complete precision) as "tort opinions." The tort opinions are 47 or 31 percent of the full set of 150 opinions. Of those, 13 we consider liberal, 28 percent of the tort opinions. The corresponding illustration of the tort opinions is figure 3 . The thick line connects the centers of gravity of the conservative and the liberal majorities and is quite different from that of the prior figure.

We perceive figure 3 as significantly different from the prior figure of all the opinions and especially the subsequent figures of other subject matters. Once the focus of attention narrows to tort opinions, a single conservative majority appears to dominate, that of Shepard-Boehm-Sullivan at about the seven o'clock position. The liberal opinions are few. Many of the liberal opinions come from majorities separated by one swing vote from the one above, from the majority Dickson-Rucker-Sullivan at ten o'clock from the swing of Sullivan, but mostly from the majority of Boehm-Dickson-Rucker at eleven o'clock from the swing of Boehm. Boehm appears as an important swing vote, but between two different majorities than those that appeared most opposed while the focus was on all opinions. 


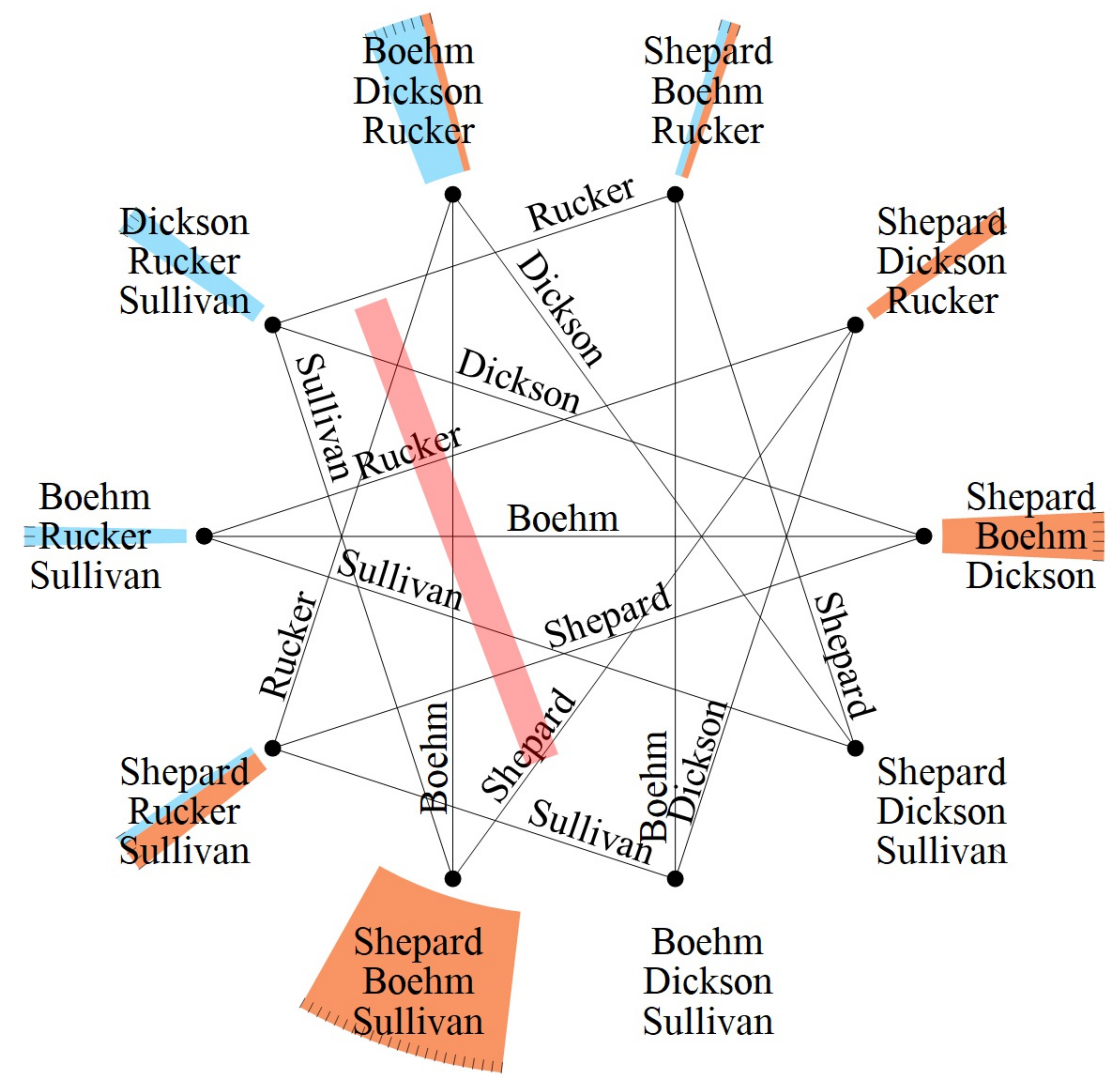

Figure 3. The opinions about private liability ("tort") and line connecting their centers of gravity.

\section{The Criminal Procedure Opinions}

The next largest grouping of opinions is about criminal procedure, 42 opinions or 28 percent of the sample of 150 opinions. Of those we consider nine to be liberal, 21 percent. Figure 4 illustrates the criminal procedure opinions following the same methods. The thick line connects the centers of gravity of liberal and conservative opinions.

Again, the figure reveals a very different pattern than that of tort opinions. The conservative opinions do not come from a single dominant majority; two majorities produce more than their share but do not dominate. Conservative opinions also come from majorities that were not very conservative in the overall mix of opinions, from Boehm-Dickson-Rucker at eleven o'clock, and from Shepard-Rucker-Sullivan at eight o'clock. The slope of the line connecting the centers of gravity of liberal and conservative opinions is very different from the slope of the corresponding tort line that we saw in the previous figure. The 
reliably conservative vote is Shepard's and the reliably liberal vote is Rucker's. The swing votes are Boehm, Dickson, and Sullivan and their ranking is unclear.

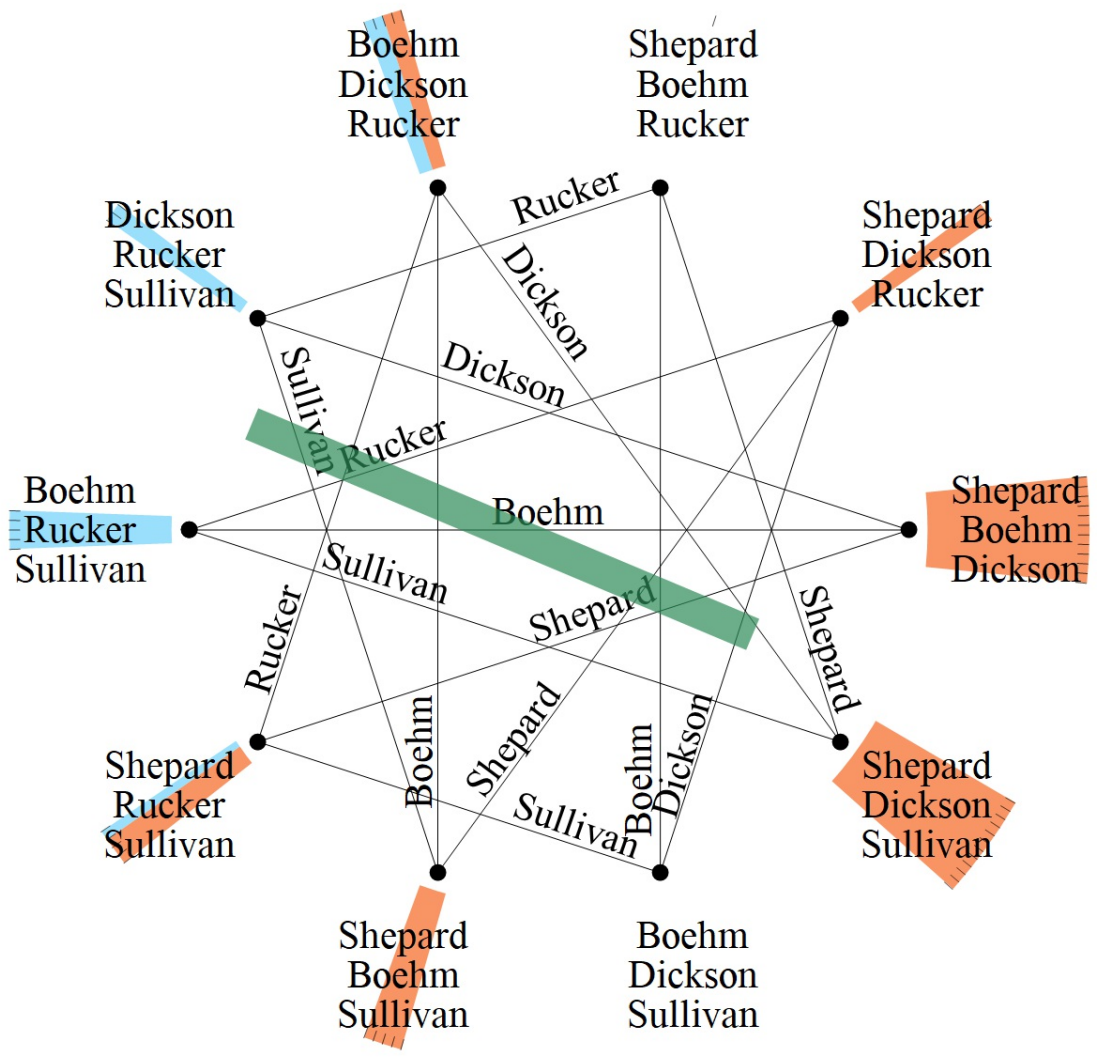

Figure 4. The criminal procedure opinions and line connecting their centers of gravity.

\section{The Sentencing Opinions}

The last significant grouping of opinions comes from the conglomeration of opinions we characterize as "sentencing" although the grouping is comprised of cases not only about sentencing but also sanctions against violations of professional responsibility by attorneys or judges, and criminal law. Those add up to 38 opinions, i.e., 25 percent of the entire set of 150 . Seventeen we identify as liberal, 44 percent. Figure 5 illustrates them following the same methods. The line connecting the centers of gravity is again shown. 


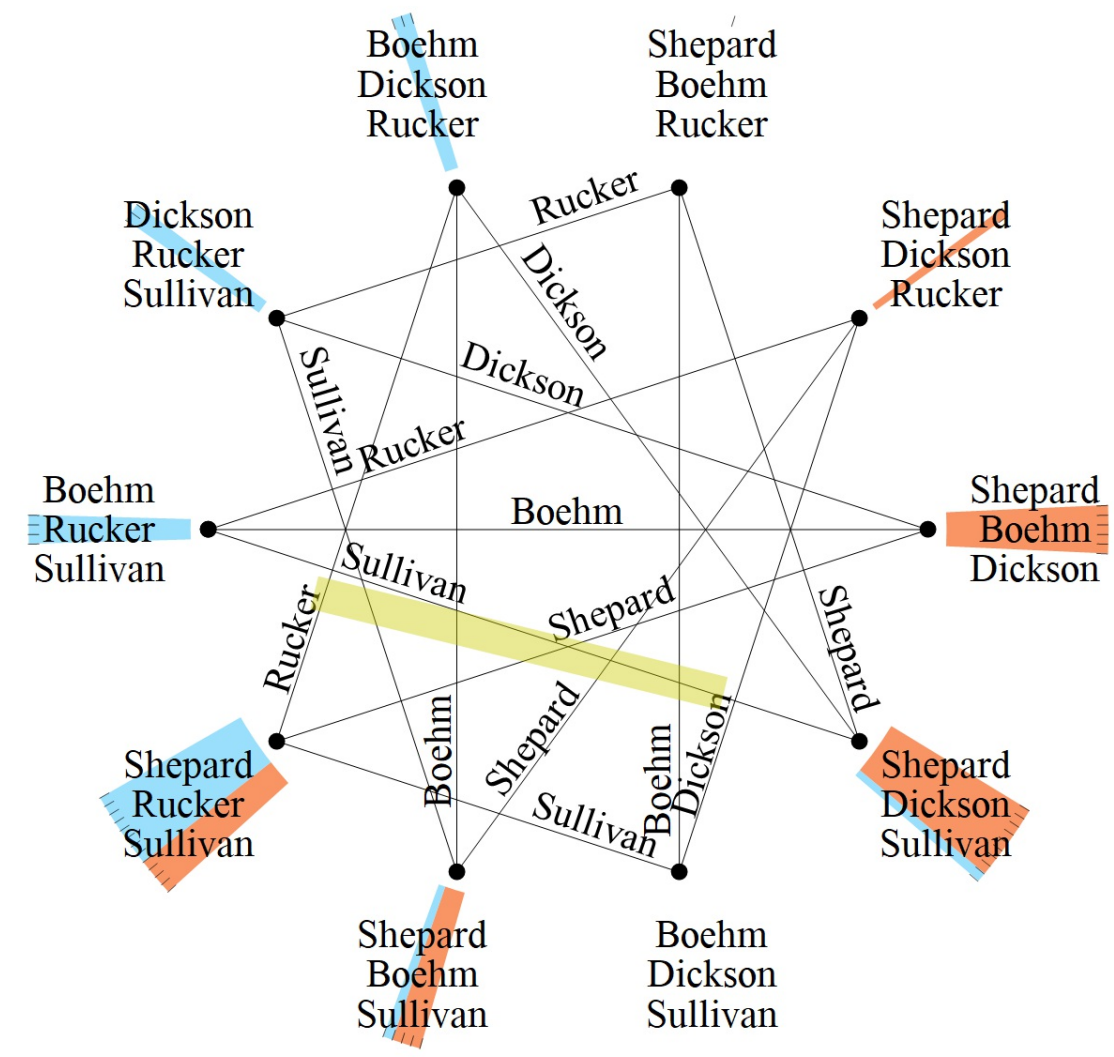

Figure 5. The sentencing, professional responsibility, and criminal law opinions of the Rucker court and the line connecting their centers of gravity.

Notice that although the line connecting the centers of gravity has about the same slope as in criminal procedure, it is shorter, reflecting the fact that both the conservative and the liberal majorities of the sentencing opinions are more scattered than they were in criminal procedure. Even more than in the prior figures, no dominant majorities and no dominant swing votes emerge. Surprisingly, the majority that forms the most often, that of Shepard-Rucker-Sullivan at the eight o'clock position, issues opinions of both liberal and conservative slants (in an eight-to-three ratio or 73 percent liberal). That same majority that appears mostly liberal here appears mostly conservative in tort and in criminal procedure and evenly split overall.

\section{E. The Remaining Opinions}

Twenty-four opinions remain outside the above three categories or 16 percent of the set of 150 opinions. By area of law they divide into two groups of seven, two groups of four and two ungrouped opinions. 


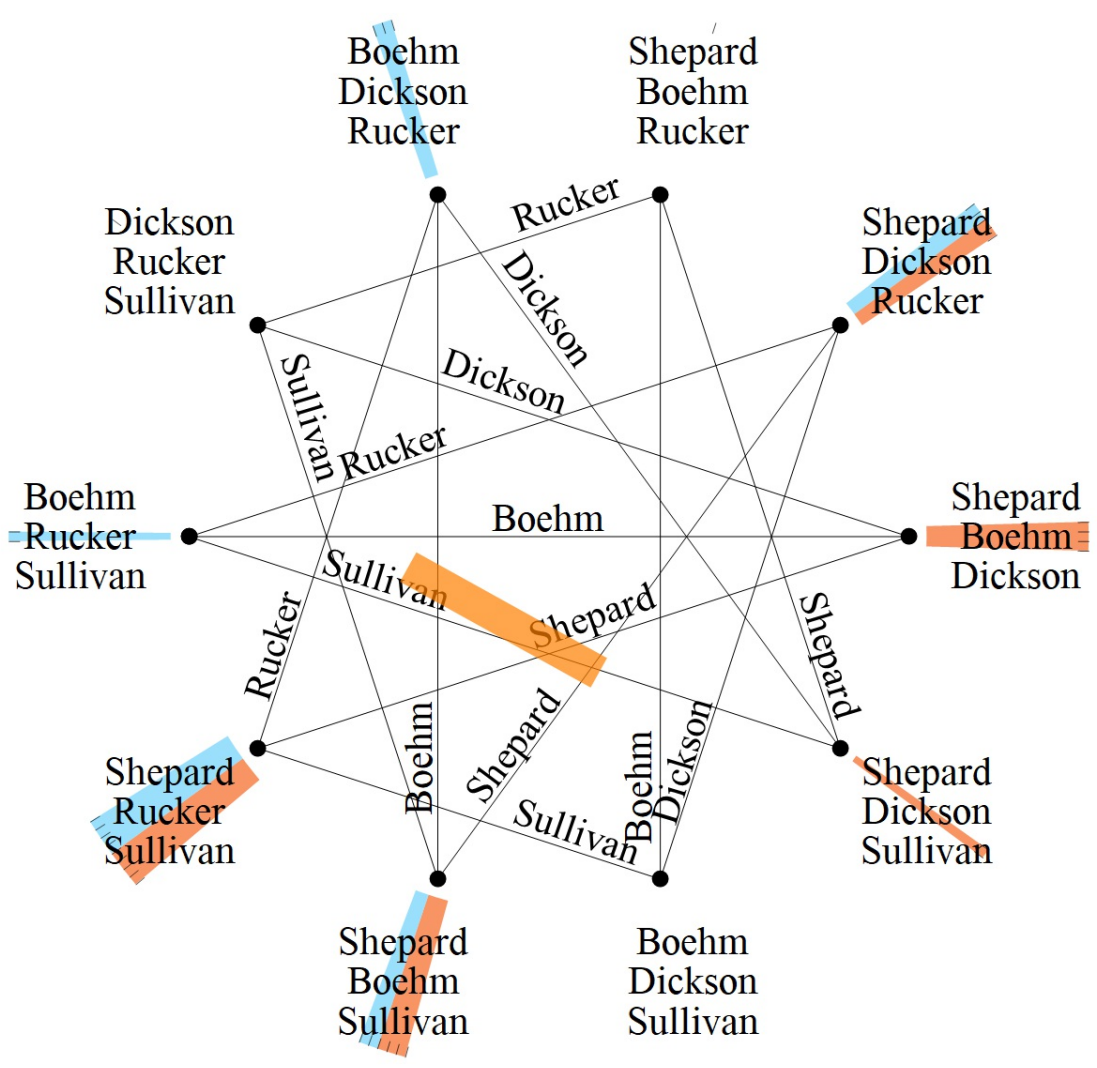

Figure 6. The remaining opinions of the Rucker court and the line connecting their centers of gravity.

Seven opinions involve the administration of the state and the courts (three liberal). ${ }^{12}$ Of those, four come from the majority of Shepard-Rucker-Sullivan at

12. Hughes v. City of Gary, 741 N.E.2d 1168 (Ind. 2001) (denying challenge by minority of city council to majority's project; majority: Shepard-Boehm-Dickson; conservative); Nw. Sch. Corp. v. Linke, 763 N.E.2d 972 (Ind. 2002) (allowing drug testing of students in various settings; majority: Shepard-Dickson-Sullivan; conservative); Ind. State Univ. v. LaFief, 888 N.E.2d 184 (Ind. 2008) (non-reappointment of professor triggers unemployment benefits, dissent would have considered employment for term; majority: Shepard-Boehm-Sullivan; liberal); City of Gary v. Ind. Bell Tel. Co., 732 N.E.2d 149 (Ind. 2000) (allowing city to impose fees on use of its property by telecommunications company; majority: Shepard-Rucker-Sullivan; liberal); Noble Cty. v. Rogers, 745 N.E.2d 194 (Ind. 2001) (landowner's counterclaim against county for not granting license properly barred; majority: Shepard-Rucker-Sullivan; liberal as pro-municipality); Fackler v. Powell, 839 N.E.2d 165 (Ind. 2005) (marital dissolution court retains jurisdiction to interpret mortgage assigned by the decree, dissent would assign to local court; majority: Shepard-Rucker-Sullivan; conservative for preventing forum-shopping); St. Joseph Cty. Comm'rs 
the eight o'clock position, and one each from the majorities at the three, four, and seven o'clock positions. Seven opinions involve real estate (two liberal). ${ }^{13}$ Four involve family law (half liberal). ${ }^{14}$ Four opinions regard state tax (three liberal). ${ }^{15}$ And some are unique (two opinions, one liberal). ${ }^{16}$ The liberal ones are 11, or 46

v. Nemeth, 929 N.E.2d 703 (Ind. 2010) (in dispute between county and probate court, approves cost-cutting renovations, denies salary increases, remands on land sale, dissent concurs in all except land sale, would affirm lower court which vacated mandate not to sell without court's consent; majority: Shepard-Rucker-Sullivan; conservative as pro-judge).

13. 600 Land, Inc. v. Metro. Bd. of Zoning Appeals of Marion Cty., 889 N.E.2d 305 (Ind. 2008) (not requiring special permit for solid waste station at truck stop; majority: Dickson-Rucker-Sullivan; conservative); Tippecanoe Assocs. II v. Kimco Lafayette 671, Inc., 829 N.E.2d 512 (Ind. 2005) (finding unenforceable restrictive covenant to prevent lease to competitor when original lessee subleases property for different use; majority: Boehm-Dickson-Rucker; liberal); Myers v. Leedy, 915 N.E.2d 133 (Ind. 2009) (lessee retains lease despite voiding of transfer to lessor because initial transferor did not join lessor; majority: Boehm-Dickson-Rucker; liberal); Fraley v. Minger, 829 N.E.2d 476 (Ind. 2005) (denying adverse possession due to nonpayment of some taxes; majority: Shepard-Boehm-Dickson; conservative); Villas W. II of Willowridge Homeowners Ass'n v. McGlothin, 885 N.E.2d 1274 (Ind. 2008) (reversing disparate impact striking of prohibition by HOA against leasing; majority: Shepard-Boehm-Dickson; conservative); Turley v. Hyten, 772 N.E.2d 993 (Ind. 2002) (landlord keeps deposit of destructive tenant despite not complying with some notice requirements; majority: Shepard-Boehm-Sullivan; conservative); State v. Kimco of Evansville, Inc., 902 N.E.2d 206 (Ind. 2009) (reconfiguration of roads through shopping mall not a taking; majority: Shepard-Boehm-Sullivan; conservative).

14. King v. S.B., 837 N.E.2d 965 (Ind. 2005) (allowing same-sex partner to seek parental rights; majority: Boehm-Rucker-Sullivan; liberal); Vadas v. Vadas, 762 N.E.2d 1234 (Ind. 2002) (husband's father's house not marital property despite plans; majority: Shepard-Dickson-Rucker; conservative); Neal v. DeKalb Cty. Div. of Family \& Children, 796 N.E.2d 280 (Inc. 2003) (allowing mother to reverse termination of parental rights she had signed; majority: Shepard-Dickson-Rucker; liberal); Grant v. Hager, 868 N.E.2d 801 (Ind. 2007) (allowing payment of child support by custodial parent to noncustodial; majority: Shepard-Rucker-Sullivan; conservative).

15. Ind. Dep't of State Revenue v. Farm Credit Servs. of Mid-Am., ACA, 734 N.E.2d 551 (Ind. 2000) (federal agricultural credit association not subject to tax of long term mortgage interest but taxed on short term, dissent would tax all; majority: Shepard-Dickson-Rucker; conservative); Ind. Dep't of Revenue v. Kitchin Hospitality, LLC, 907 N.E.2d 997 (Ind. 2009) (denying hotel's argument for tax exemption and reversing specialized tax court which dissent would affirm; majority: Shepard-Boehm-Sullivan; liberal); State v. Adams, 762 N.E.2d 728 (Ind. 2002) (improperly found cocaine can still be taxed; majority Shepard-Rucker-Sullivan; liberal as progovernment); Ind. Dep't of State Revenue v. Belterra Resort Ind., LLC, 935 N.E.2d 174 (Ind. 2010) (acquisition of riverboat subject to sales tax as retail transaction; majority: Shepard-Rucker-Sullivan; liberal as pro-government).

16. Pabey v. Pastrick, 816 N.E.2d 1138 (Ind. 2004) (ordering special election in disputed mayoral election; majority: Shepard-Dickson-Rucker; liberal); Ind. High Sch. Athletic Ass'n v. Martin, 765 N.E.2d 1238 (Ind. 2002) (HS player not allowed to play for new school but appeal did not violate injunction, dissent would have allowed athlete to play; majority: 
percent, of the remaining opinions, giving this subset the highest ratio of liberal opinions. Figure 6 illustrates them.

The problem with Figure 6 is that the data are thinning out. Each majority issues a few opinions. Several majorities issue both liberal and conservative opinions. The line connecting the centers of gravity is short, reflecting the notion that the court's majorities are very fluid, and do not group themselves systematically in the sense that liberal and conservative opinions come from many majorities in a way very different from the arrangement of the majorities on the basis of their overall leanings.

In sum, centers of gravity reveal two features. Their distance (the length of the line) increases with polarization. The observation that the lines corresponding to different subject matters have different slopes shows that the justices form systematically different coalitions by subject matter.

\section{CONCLUSION}

The graphical representations of the tightly split opinions open several avenues for further research, some of which we are pursuing. One can try to apply this analysis to the United States Supreme Court and observe how its patterns change over time. The focus on swing votes may also allow further elaboration of the allocation of opinion authorship and the relative importance of different justices as swing votes for the advocates. One could also use this analysis as a stepping stone for juxtaposing actual judging with locational models of judicial voting based on the median voter theorem.

This analysis may also be relevant to the debates about efficiency of the common law and the victory rate of plaintiffs. The argument about the efficiency of the common law springs from the idea that interpretations that produce problems will attract litigation, and therefore be more likely to change. However, the dominance of criminal procedure and criminal law in the docket of the Indiana Supreme Court suggests that other forces predominate. Turning to the rate of victory, the data are not directly relevant, because the disputes are filtered by the Court's decision to review a matter, akin to the granting of certiorari. The result of this filtering, however, is not an even split between liberal and conservative outcomes, as one might expect, but skew conservative; strikingly almost 80 percent in criminal procedure, and over 70 percent in tort.

This graphical sojourn over supreme court swing votes sounds an upbeat note. The Indiana Supreme Court used most of its majorities and most of its majorities produced both liberal and conservative opinions. The upbeat message is that, rather than political leanings, law or, rather, the justices' personal legal philosophies, mattered in the disposition of disputes that produced tight splits. Personal legal philosophies, in other words, visibly dominated political leanings. The court aligned differently for matters of civil liability (what we called "tort") than on other matters, especially criminal procedure. 


\section{APPENDIX A: THE INDIANA DATA AND THE PLACEMENT OF THE MAJORITIES}

\section{THE DATA}

The Indiana data begin as the 174 opinions identified as 3-2, "tightly split," opinions in our previous joint work. ${ }^{17}$ These are the tightly split opinions issued by the unchanged composition of the Indiana Supreme Court from 1999 to 2010, the composition defined by the junior justice being Rucker. The difficulty of generalizing from this data becomes clearer if we juxtapose those 174 opinions to the 191 tightly split opinions of the Breyer composition, the United States Supreme Court from November 1994, to June 2005. Seventy-two percent of those 191 opinions, 141 opinions, come from three coalitions that are separated by two swing votes, Kennedy and O'Connor. The minority in 46 percent of that total has Justices Breyer, Ginsburg, Souter, and Stevens. The other two groups have these justices in the majority, joined by either O'Connor, in thirty-one opinions, or Kennedy, in twenty-two opinions.

The opinions of the Indiana court do not allow such an easy identification of its swing votes. The tightly split opinions that we study come from nine majorities (out of the possible ten for a five-member court), each in significant proportions. A listing of the Indiana tightly split opinions, a one-sentence summary, and their subject matter and political slant appear in Appendix B.

We explain here how we produced figure 1 of the main text.

\section{ARRANGING THE MAJORITIES}

We arrange the majorities in a circle in such a way as to observe the opposition of majorities separated by a single swing vote. Having coded the opinions as liberal or conservative ourselves by comparing the position of the majority with that of the dissent, we identified the two most contrary majorities, defined as the one that issued the highest percentage of conservative opinions and one that issued the highest percentage of liberal opinions.

One majority issues 100 percent conservative opinions. Two majorities issue 100 percent liberal opinions, but as one opinion of one of these majorities is borderline conservative, we use the other majority as the most liberal one. Since these are tightly split opinions, the most liberal majority and the most conservative one must share a justice. The majority that produces only conservative opinions is Shepard, Boehm, and Dickson; Rucker, with Sullivan, form the dissent. The most liberal majority is Boehm, Rucker, and Sullivan;

17. Sullivan, Georgakopoulos \& Georgakopoulos, supra note 1. The opinions were compiled by Dimitri Georgakopoulos from Table D of the annual Examination of the Indiana Supreme Court Docket, Dispositions, and Voting, compiled under the direction of Kevin W. Betz (1999-2004) and Mark J. Crandley (2005-2010) and assisted by P. Jason Stephenson and other authors and published by the Indiana Law Review in vols. 33-44 (2000-2011), respectively. 
Shepard, with Dickson, form the dissent. ${ }^{18}$ The swing vote is Boehm.

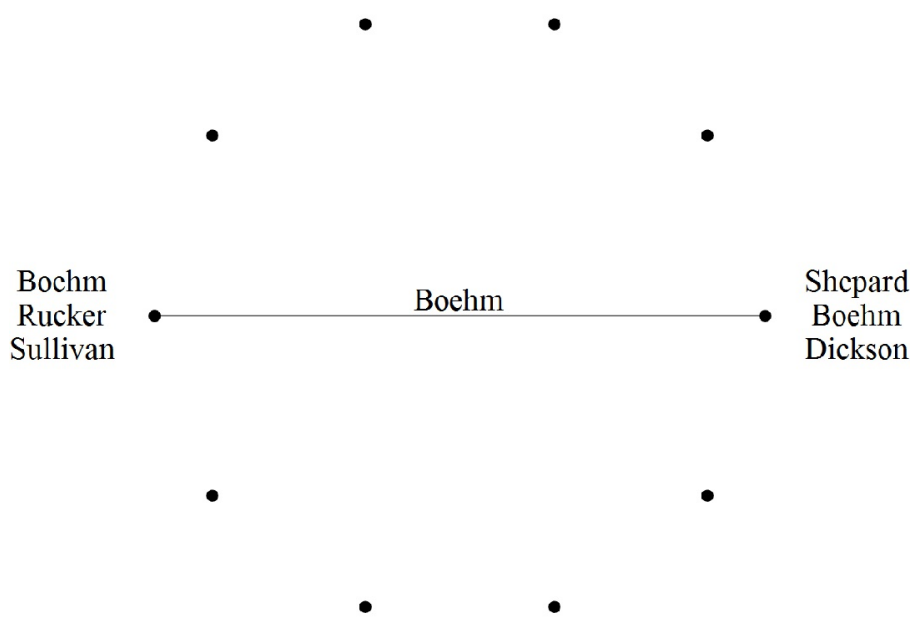

Figure A1. Placing the two most ideologically opposed majorities in the circle of all ten possible majorities.

Because the ideological opposition of these two coalitions is the sharpest, we consider their opposition the most salient. Accordingly, we begin the arrangement of the majorities by placing those two on opposite sides and connect them with a line marked Boehm as the swing vote that links them. We place the conservative Shepard-Boehm-Dickson majority at the (rightmost) three o'clock position and the liberal Boehm-Rucker-Sullivan majority across it, at the nine o'clock position. Since the possible majorities are ten, each side of the circle has five positions, two above and two below each one of these two majorities, as in figure A1.

As each majority has three justices, each of these two most ideologically opposed majorities that are separated by the swing vote of Boehm has two other potential swing votes. Because the objective is to illustrate the opposition between majorities that are separated by a swing vote, the majorities that result from those swing votes should also be across the circle. For example, from the majority Shepard-Boehm-Dickson, the other swing votes are Shepard and Dickson, forming the majorities Shepard-Rucker-Sullivan and Dickson-Rucker-Sullivan. We place the majority that issued the greater proportion of liberal opinions in the position above the already placed

18. A second majority, Dickson-Rucker-Sullivan, also issues only liberal opinions but we consider this majority as less saliently liberal than Boehm-Rucker-Sullivan because it forms less often. Also, some of its opinions have only a marginally liberal slant. Transposing those two majorities would not alter any of the phenomena we discuss except the rotational symmetry of figure A3. 
oppositional majority and the other one below it. Again, a connecting line identifies each swing vote. The result is figure A2.

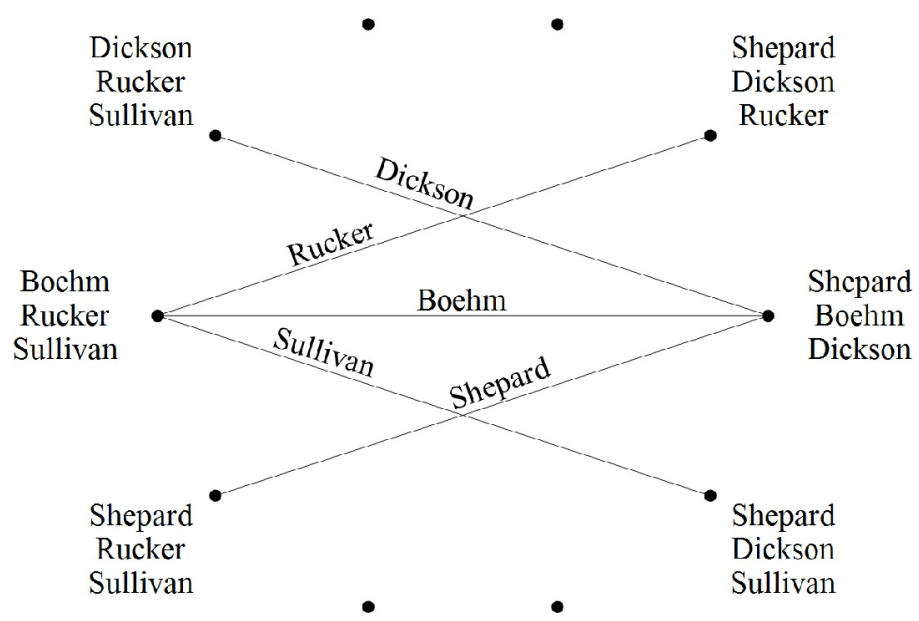

Figure A2. Placing the next four opposing majorities.

Four positions (points) remain without an assigned majority in figure A2. Three majorities that have issued opinions remain unplaced; one potential majority never formed to issue any opinions. Since we broke the tie placing the more liberal majorities above the first two, we also place the next most liberal majority, Boehm-Dickson-Rucker, upwards, at the eleven o'clock position, the first position on the left half of the circle above those already occupied. Two of its swing votes are already placed, the swing of Dickson to Shepard-Dickson-Sullivan at the four o'clock position, and that of Rucker to Shepard-Rucker-Sullivan at the eight o'clock position. The remaining swing vote is Boehm and the resulting majority, Shepard-Boehm-Sullivan, still unplaced, goes to the lower end of the circle to stress opposition. A single majority that has issued opinions remains unplaced, Shepard-Boehm-Rucker. Its placement seems to be more natural at the one o'clock position, where it shares two justices with both its neighbors. This leaves the five o'clock position for the majority that issued no opinions, Boehm-Dickson-Sullivan. Figure A3 shows the result.

Interestingly, the resulting star-like diagram has symmetry. Flipping the diagram along its horizontal centrally dividing line, the line that corresponds to Boehm as the main swing vote, produces the same shape. 


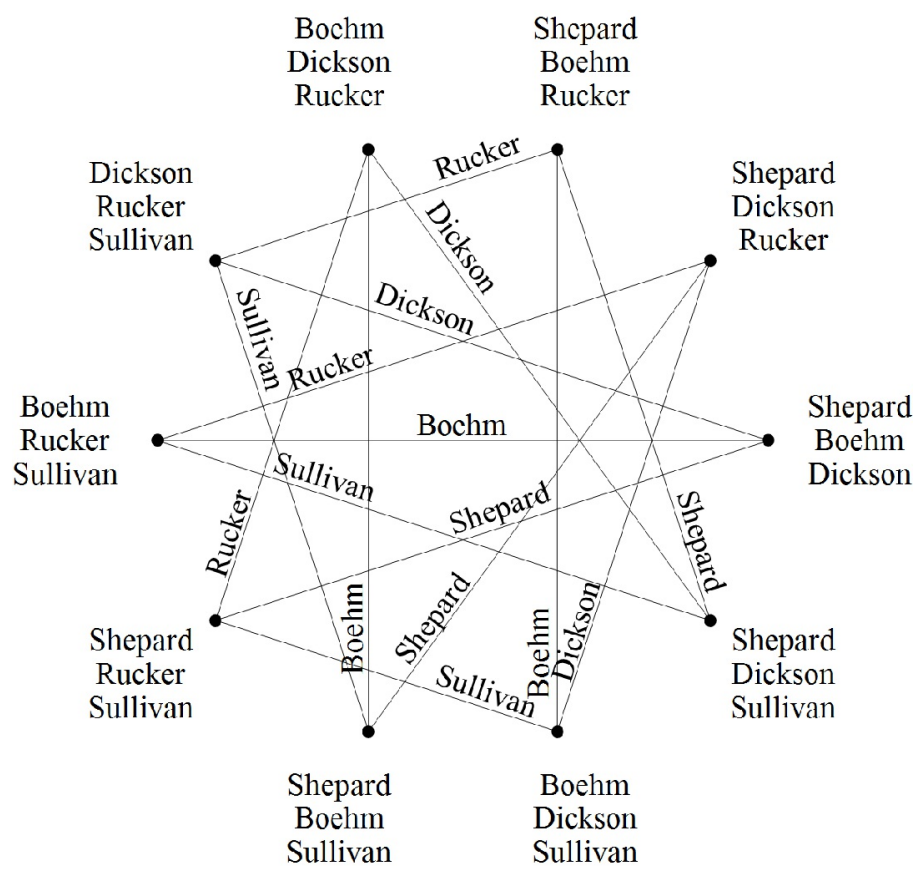

Figure A3. The web of all majorities and swing votes.

The purpose of arranging the majorities is to be able to visualize the opinions. Having arranged the ten possible majorities in opposition around a circle, each one of the ten points that correspond to each majority is the point at which its opinions should appear. Figure 1 illustrates the 150 opinions that remain in the sample after we drop several that we do not consider orthodox tightly split opinions. Most of the dropped opinions involve concurrences rather than dissents. Some, however, we consider atypical because the two dissenting justices take positions ideologically opposite from each other, making the majority position the centrist one. ${ }^{19}$

19. A typical example is In re Fieger, 887 N.E.2d 87 (Ind. 2008) (per curiam). The opinion is about professional responsibility and imposes a temporary ban from temporary admission to the Indiana Bar on a lawyer from a different jurisdiction. One dissent would permanently ban the offending lawyer whereas the other would exonerate him. 


\section{APPENDIX B: TABLES OF OPINIONS PER MAJORITY}

We list the opinions in the sample in nine tables, by majority, starting with Boehm - Rucker - Sullivan, the most liberal majority at the nine o'clock position of the figures and proceeding clockwise. The first column contains the opinion and its citation. The second column contains our extremely brief (and admittedly almost cryptic) summary of the majority and the dissent. The third column contains our coding, i.e., either our categorization of the area of law of the opinion and the liberal or conservative slant of the majority compared to the dissent or that the opinion was dropped from the sample. We underscore that the political slant of the opinion is the result of the comparison of the majority to the dissent. In the few cases where two dissents take political positions on either side of the majority, we drop the opinion because the outcome of the majority is the centrist one. The ordering of the justices in each majority is, first, the chief justice, and then the associate justices alphabetically. 
INDIANA SUPREME COURT

\title{
A. Boehm-Rucker-Sullivan (Nine o'Clock Position)
}

\author{
In re Miller, 730 \\ Lawyer suspension of $1 \mathrm{yr}$ for being paid out of \\ Sent'g/PR/Crim'l; \\ N.E.2d 171 (Ind. 2000) \\ client funds was warranted. Dissent considers the \\ (per curiam). \\ sanction insufficient. \\ Ashabraner v. Bowers, \\ Negligence jury trial, use of peremptory \\ Liberal. \\ 753 N.E.2d 662 (Ind. \\ challenges racially discriminatory. Dissent would \\ 2001) (Sullivan, J.). \\ uphold trial court's denial of discrimination. \\ In re Harshey, 740 \\ Atty reprimanded for causing acceptance of \\ N.E.2d 851 (Ind. 2001) \\ settlement client rejected. Dissent considers \\ sanction insufficient. \\ (per curiam). \\ Death penalty; sentence vacated. Dissents find \\ Azania v. State, 778 \\ jury selection and composition appropriate. \\ 2002) (Boehm, J.). \\ King v. S.B., 837 \\ Same-sex partner can seek parental rights. \\ Other; Liberal. \\ N.E.2d 965 (Ind. 2005) \\ Dissent 1 thinks this can be challenged later in \\ (Sullivan, J.) \\ proceedings; dissent 2 would dismiss for failing \\ to state a claim. \\ Halsema v. State, 823 \\ Meth possession; lessee could not consent to \\ CrimPro; Liberal. \\ N.E.2d 668 (Ind. 2005) \\ search, metric measurement of drugs confusing to \\ (Rucker, J.). \\ the jury. Dissent finds lessee's consent sufficient. \\ Sellmer v. State, 842 \\ Marijuana possession; anonymous call not \\ N.E.2d 358 (Ind. 2006) \\ grounds for reasonable suspicion, car search \\ (Sullivan, J.) \\ needed proper warning. Dissent finds the \\ suspicion reasonable. \\ Stephenson v. State, \\ Burglary conviction; errors harmless. \\ Sent'g/PR/Crim'l; \\ Liberal. \\ CrimPro; Liberal. \\ 864 N.E.2d 1022 (Ind. \\ 2007) (Boehm, J.). \\ Concurrence underlines experience and resources \\ of defense. \\ In re Colman, 885 \\ Attorney's 3yr suspension with readmission \\ subject to conditions appropriate. Dissents would \\ Sent'g/PR/Crim'l; \\ N.E.2d 1238 (Ind. \\ disbar. \\ Cent. Ind. Podiatry, \\ Podiatrist move escaped reasonable limits of \\ CrimPro; Liberal. \\ P.C. v. Krueger, 882 \\ noncompete agreement. Dissent would enforce. \\ Dropped. \\ N.E.2d 723 (Ind. 2008) \\ (Boehm, J.).
}




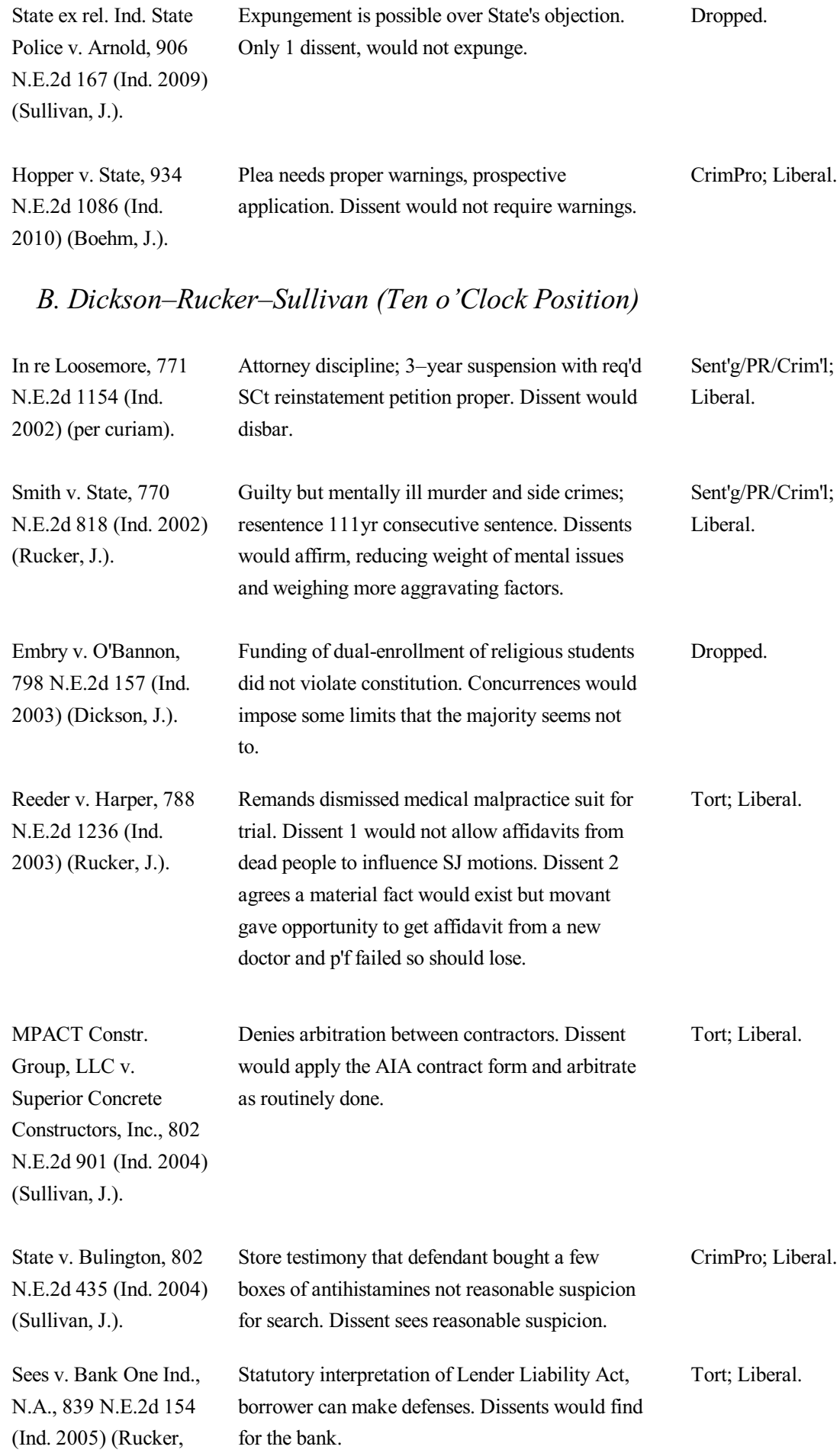

\section{B. Dickson-Rucker-Sullivan (Ten o'Clock Position)}

In re Loosemore, $771 \quad$ Attorney discipline; 3-year suspension with req'd N.E.2d 1154 (Ind. $\quad$ SCt reinstatement petition proper. Dissent would 2002) (per curiam). disbar.

Smith v. State, 770

N.E.2d 818 (Ind. 2002)

(Rucker, J.).

Embry v. O'Bannon, 798 N.E.2d 157 (Ind.

2003) (Dickson, J.).

Reeder v. Harper, 788

N.E.2d 1236 (Ind.

2003) (Rucker, J.).

MPACT Constr.

Group, LLC v.

Superior Concrete

Constructors, Inc., 802

N.E.2d 901 (Ind. 2004)

(Sullivan, J.).

State v. Bulington, 802

N.E.2d 435 (Ind. 2004)

(Sullivan, J.).

Sees v. Bank One Ind., N.A., 839 N.E.2d 154 (Ind. 2005) (Rucker,

Guilty but mentally ill murder and side crimes; resentence $111 \mathrm{yr}$ consecutive sentence. Dissents would affirm, reducing weight of mental issues and weighing more aggravating factors.

Funding of dual-enrollment of religious students did not violate constitution. Concurrences would impose some limits that the majority seems not to.

Remands dismissed medical malpractice suit for trial. Dissent 1 would not allow affidavits from dead people to influence SJ motions. Dissent 2 agrees a material fact would exist but movant gave opportunity to get affidavit from a new doctor and p'f failed so should lose.

Denies arbitration between contractors. Dissent would apply the AIA contract form and arbitrate as routinely done.

Store testimony that defendant bought a few boxes of antihistamines not reasonable suspicion for search. Dissent sees reasonable suspicion.

Statutory interpretation of Lender Liability Act, borrower can make defenses. Dissents would find for the bank.

Sent'g/PR/Crim'l; Liberal.

Sent'g/PR/Crim'l; Liberal.

Dropped.

Tort; Liberal.

Tort; Liberal.

CrimPro; Liberal.

Tort; Liberal.

J.). 


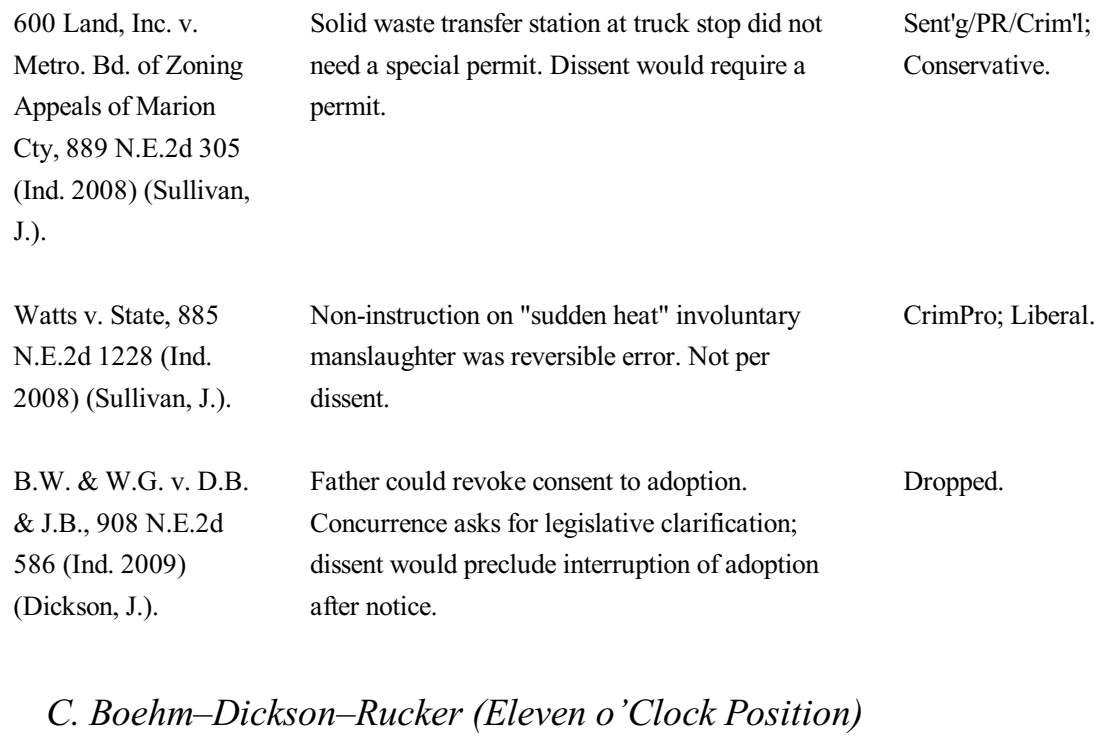

\section{Boehm-Dickson-Rucker (Eleven o'Clock Position)}

Sent'g/PR/Crim'l;

Conservative.

CrimPro; Liberal.

Dropped.

\begin{abstract}
Cavinder Elevators, Inc. v. Hall, 726 N.E.2d 285 (Ind. 2000)

(Dickson, J.)

Tort (fallen elevator); allows trial on later discovered evidence. Dissent is procedural; the fact that court ruled later than 30 days after motion to correct should have been deemed a denial, which movant should have appealed.
\end{abstract}

Jiosa v. State, 755

N.E.2d 605 (Ind. 2001)

(Boehm, J.).

Segura v. State, 749

N.E.2d 496 (Ind. 2001)

(Boehm, J.).

Ray-Hayes v.

Heinamann, 768

N.E.2d 899 (Ind. 2002)

(Boehm, J.).

Davidson v. State, 763 N.E.2d 441 (Ind. 2002) (Boehm, J.).
Error not to allow mother to testify in favor of child molestation defendant. Dissent would not allow testimony after violation of order separating witnesses.

Not advising about deportation in cocaine plea not reversible error. Concurrence explains burden on the argument of ineffective assistance in pleas but that would likely facilitate overturning pleas.

Allows prospective only application of interpretation that time-barred products liability claim. Dissent would deny rehearing.

Robbery and related crimes; no ineffective assistance of counsel. Concurrence that no grounds for defenses arise.
Tort; Liberal.

CrimPro; Liberal.

CrimPro;

Conservative.

Tort; Liberal.

Dropped 
Indep. Dep't of Envtl. Mgmt. v. Twin Eagle LLC, 798 N.E.2d 839 (Ind. 2003) (Boehm, J.).

Booth v. Wiley, 839

N.E.2d 1168 (Ind.

2005) (Dickson, J.).

Tippecanoe Assoc. II

v. Kimco Lafayette

671, Inc., 829 N.E.2d

512 (Ind. 2005)

(Boehm, J.).

Timberlake v. State, 859 N.E.2d 1209 (Ind.

2007) (Dickson, acting

C. J.).

Porter Cty. Sheriff

Dep't v. Guzorek, 857

N.E.2d 363 (Ind. 2006)

(Boehm, J.).

In re Estate of

Hammar, 847 N.E.2d

960 (Ind. 2006)

(Dickson, J.).

Newton v. State, 894

N.E.2d 192 (Ind. 2008)

(Dickson, J.).

Holly v. State, 918

N.E.2d 323 (Ind. 2009)

(Rucker, J.).
Clean Water Act dispute of developer against state; IDEM may require permits, remand.

Concurrence sees matter not ripe, to the polluter's advantage.

Glaucoma LASIC malpractice; limitations start on discovery, remand. Dissents would time-bar for different reasons.

Restrictive covenant to prevent lease to competitor becomes unenforceable when tenant subleases to different use. Dissent would apply as written.

Stays execution pending SCOTUS reevaluation of insanity standard. Dissents find defendant would not meet the revised insanity standard and would not stay.

Adding sheriff's department to defendant officer relates back to original filing, not time-barred.

Dissent considers that it may not be a mistake of identity and perhaps time-barred.

Trial court did not abuse discretion when it replaced ex-wife \& mother of children with decedent's widow for pursuing wrongful death claim. Concurrence would have ex-wife and her attorney reimburse widow's legal fees.

Trial court lacked authority to accept belated appeal of plea bargain. Concurrences \& dissent.

While suspended license of owner would make search pursuant to reasonable suspicion, the fact that driver was opposite sex of registered owner removed reasonableness, marijuana excluded.

Dissents argue request for license should not lead to negative results for the police.

Lessee retains lease from transferee despite voiding of transfer in favor of transferor because transferor did not join transferee. Concurrence objects to changing foreclosure consequences.
Tort; Conservative.

Tort; Liberal.

Other; Liberal.

Sent'g/PR/Crim'l;

Liberal.

Tort; Liberal.

Tort; Liberal.

Dropped.

CrimPro; Liberal.

Other; Liberal.
N.E.2d 133 (Ind. 2009)

(Rucker, J.). 


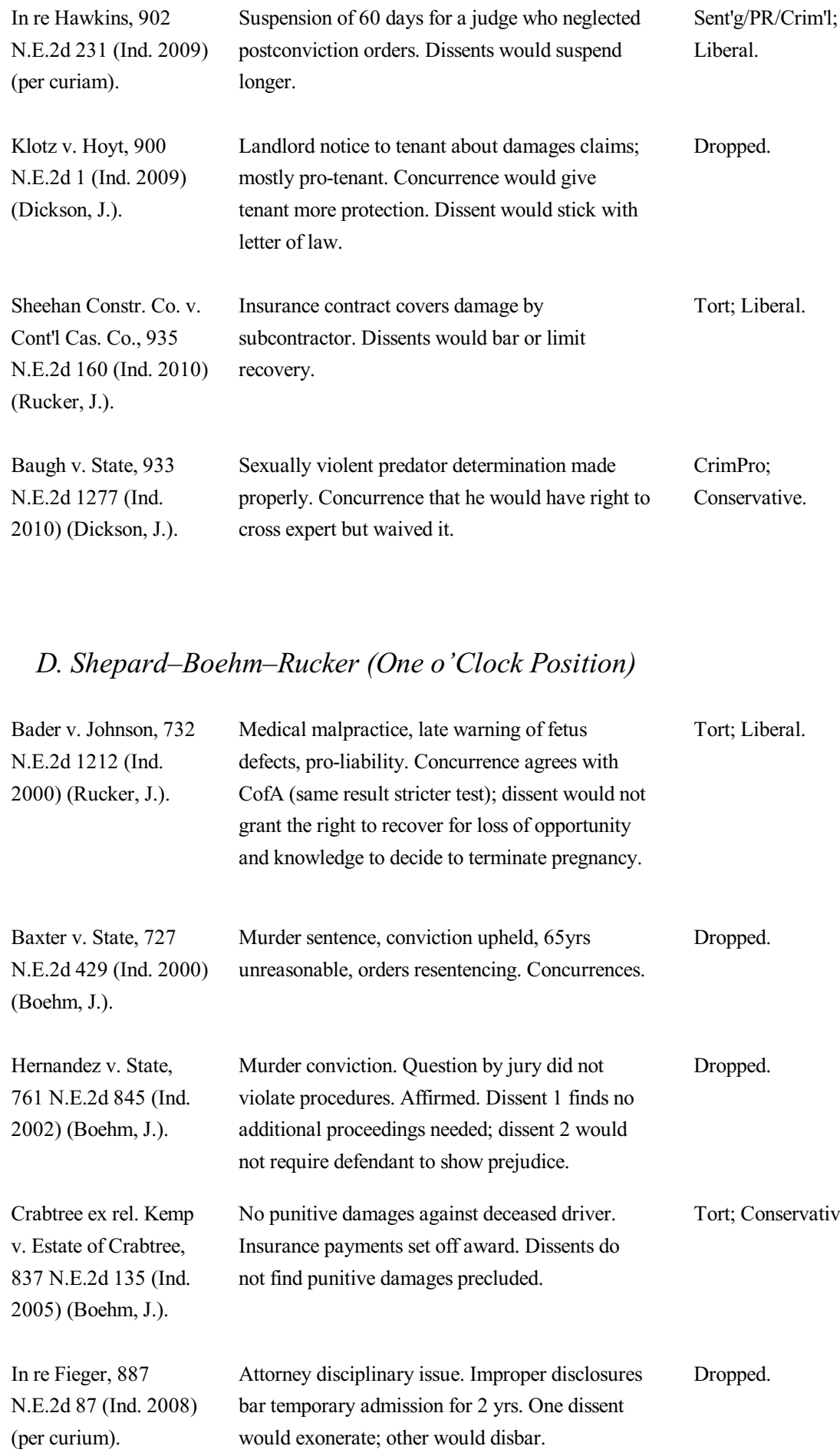

\section{Shepard-Boehm-Rucker (One o'Clock Position)}




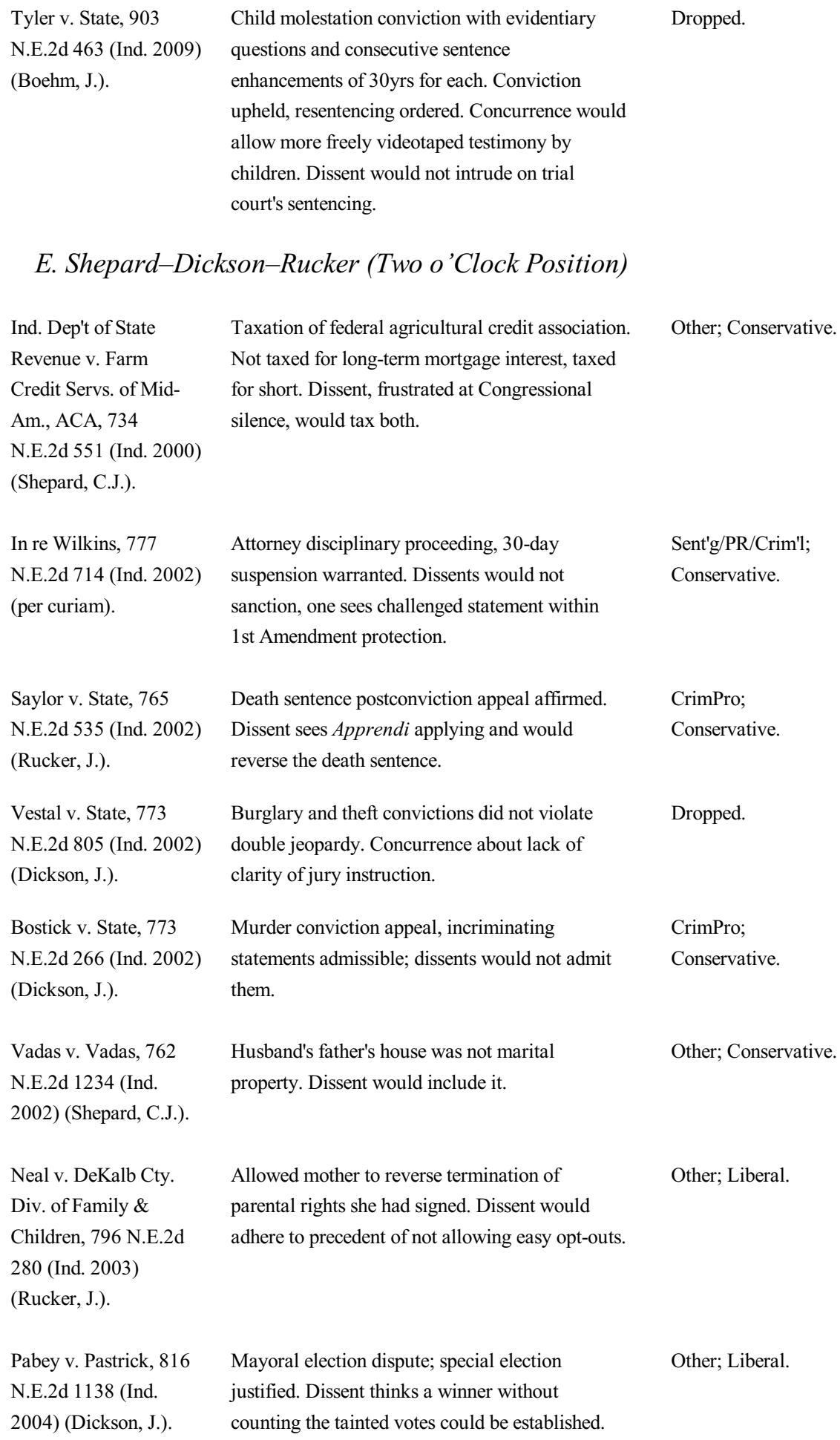

\section{E. Shepard-Dickson-Rucker (Two o'Clock Position)}

Ind. Dep't of State

Revenue v. Farm

Credit Servs. of Mid-

Am., ACA, 734

N.E.2d 551 (Ind. 2000)

(Shepard, C.J.).

In re Wilkins, 777

N.E.2d 714 (Ind. 2002)

(per curiam).

Saylor v. State, 765

N.E.2d 535 (Ind. 2002)

(Rucker, J.).

Vestal v. State, 773

N.E.2d 805 (Ind. 2002)

(Dickson, J.).

Bostick v. State, 773

N.E.2d 266 (Ind. 2002)

(Dickson, J.).

Vadas v. Vadas, 762

N.E.2d 1234 (Ind.

2002) (Shepard, C.J.).

Neal v. DeKalb Cty.

Div. of Family \&

Children, 796 N.E.2d

280 (Ind. 2003)

(Rucker, J.).

Pabey v. Pastrick, 816

N.E.2d 1138 (Ind.

2004) (Dickson, J.).

Taxation of federal agricultural credit association. Not taxed for long-term mortgage interest, taxed for short. Dissent, frustrated at Congressional silence, would tax both.

Attorney disciplinary proceeding, 30-day suspension warranted. Dissents would not sanction, one sees challenged statement within 1st Amendment protection.

Death sentence postconviction appeal affirmed. Dissent sees Apprendi applying and would reverse the death sentence.

Burglary and theft convictions did not violate double jeopardy. Concurrence about lack of clarity of jury instruction.

Murder conviction appeal, incriminating statements admissible; dissents would not admit them.

Husband's father's house was not marital property. Dissent would include it.

Allowed mother to reverse termination of parental rights she had signed. Dissent would adhere to precedent of not allowing easy opt-outs.

Mayoral election dispute; special election justified. Dissent thinks a winner without counting the tainted votes could be established.

Dropped.

Other; Conservative.

Sent'g/PR/Crim'l;

Conservative.

CrimPro;

Conservative.

Dropped.

CrimPro;

Conservative.

Other; Conservative.

Other; Liberal.

Other; Liberal. 

INDIANA SUPREME COURT

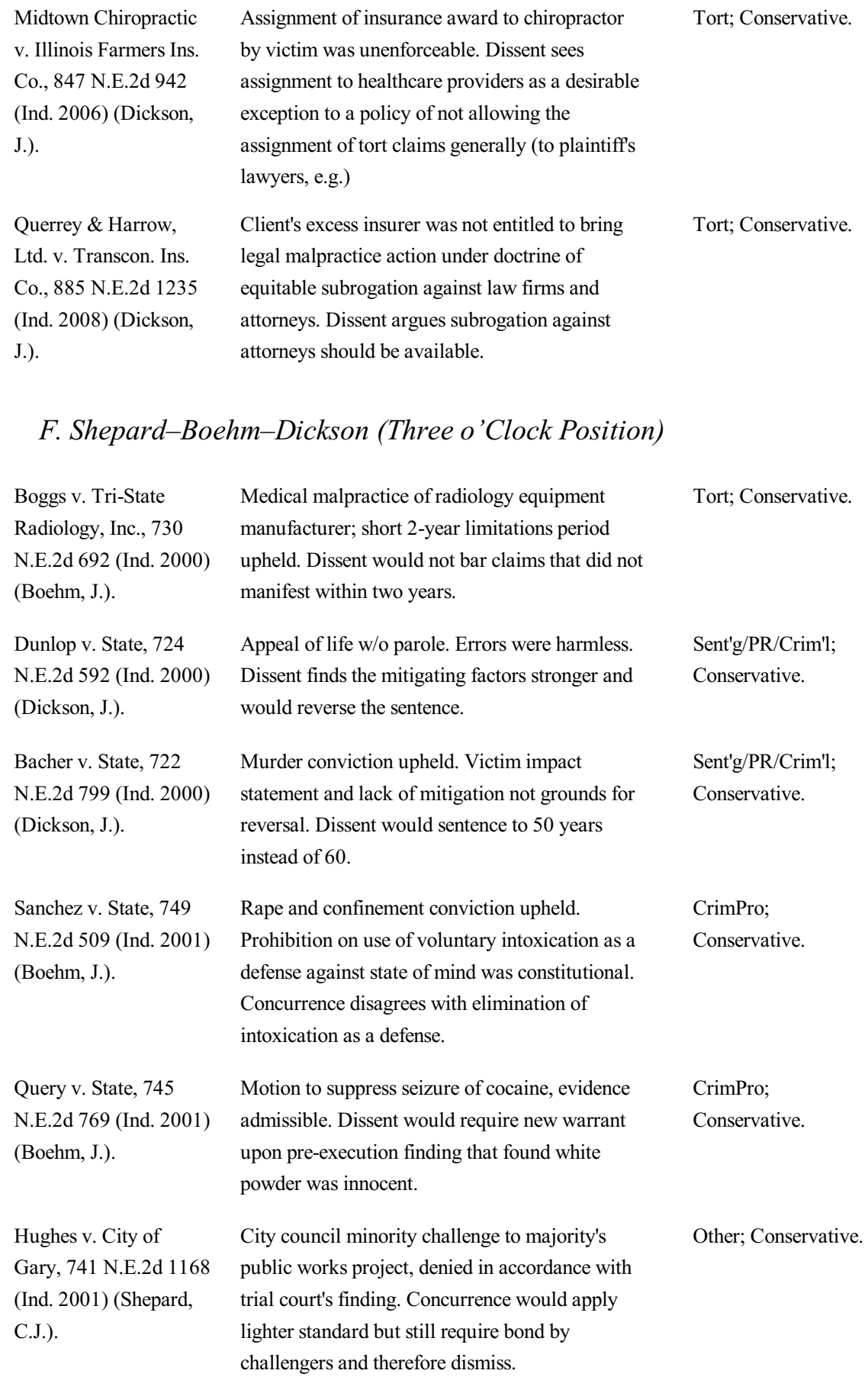

\section{F. Shepard-Boehm-Dickson (Three o'Clock Position)}

\begin{tabular}{|c|c|c|}
\hline $\begin{array}{l}\text { Boggs v. Tri-State } \\
\text { Radiology, Inc., } 730 \\
\text { N.E.2d } 692 \text { (Ind. 2000) } \\
\text { (Boehm, J.). }\end{array}$ & $\begin{array}{l}\text { Medical malpractice of radiology equipment } \\
\text { manufacturer; short } 2 \text {-year limitations period } \\
\text { upheld. Dissent would not bar claims that did not } \\
\text { manifest within two years. }\end{array}$ & Tort; Conservative. \\
\hline $\begin{array}{l}\text { Dunlop v. State, } 724 \\
\text { N.E.2d } 592 \text { (Ind. 2000) } \\
\text { (Dickson, J.). }\end{array}$ & $\begin{array}{l}\text { Appeal of life w/o parole. Errors were harmless. } \\
\text { Dissent finds the mitigating factors stronger and } \\
\text { would reverse the sentence. }\end{array}$ & $\begin{array}{l}\text { Sent'g/PR/Crim'l; } \\
\text { Conservative. }\end{array}$ \\
\hline $\begin{array}{l}\text { Bacher v. State, } 722 \\
\text { N.E.2d } 799 \text { (Ind. 2000) } \\
\text { (Dickson, J.). }\end{array}$ & $\begin{array}{l}\text { Murder conviction upheld. Victim impact } \\
\text { statement and lack of mitigation not grounds for } \\
\text { reversal. Dissent would sentence to } 50 \text { years } \\
\text { instead of } 60 \text {. }\end{array}$ & $\begin{array}{l}\text { Sent'g/PR/Crim'l; } \\
\text { Conservative. }\end{array}$ \\
\hline $\begin{array}{l}\text { Sanchez v. State, } 749 \\
\text { N.E.2d } 509 \text { (Ind. 2001) } \\
\text { (Boehm, J.). }\end{array}$ & $\begin{array}{l}\text { Rape and confinement conviction upheld. } \\
\text { Prohibition on use of voluntary intoxication as a } \\
\text { defense against state of mind was constitutional. } \\
\text { Concurrence disagrees with elimination of } \\
\text { intoxication as a defense. }\end{array}$ & $\begin{array}{l}\text { CrimPro; } \\
\text { Conservative. }\end{array}$ \\
\hline $\begin{array}{l}\text { Query v. State, } 745 \\
\text { N.E.2d } 769 \text { (Ind. 2001) } \\
\text { (Boehm, J.). }\end{array}$ & $\begin{array}{l}\text { Motion to suppress seizure of cocaine, evidence } \\
\text { admissible. Dissent would require new warrant } \\
\text { upon pre-execution finding that found white } \\
\text { powder was innocent. }\end{array}$ & $\begin{array}{l}\text { CrimPro; } \\
\text { Conservative. }\end{array}$ \\
\hline $\begin{array}{l}\text { Hughes v. City of } \\
\text { Gary, } 741 \text { N.E.2d } 1168 \\
\text { (Ind. 2001) (Shepard, } \\
\text { C.J.). }\end{array}$ & $\begin{array}{l}\text { City council minority challenge to majority's } \\
\text { public works project, denied in accordance with } \\
\text { trial court's finding. Concurrence would apply } \\
\text { lighter standard but still require bond by } \\
\text { challengers and therefore dismiss. }\end{array}$ & Other; Conservative. \\
\hline
\end{tabular}


French v. State, 778

N.E.2d 816 (Ind. 2002)

(Boehm, J.).

In re Williams, 764

N.E.2d 613 (Ind. 2002)

(per curiam).

Tincher v. Davidson,

762 N.E.2d 1221 (Ind.

2002) (Dickson, J.).

Spivey v. State, 761

N.E.2d 831 (Ind. 2002)

(Dickson, J.).

Chaffee v. Seslar, 786

N.E.2d 705 (Ind. 2003)

(Dickson, J.).

State v. Barker, 809

N.E.2d 312 (Ind. 2004)

(Dickson, J.)

Myers v. State, 839

N.E.2d 1146 (Ind.

2005) (Dickson, J.).

Fraley v. Minger, 829

N.E.2d 476 (Ind. 2005)

(Dickson, J.).

Staton v. State, 853

N.E.2d 470 (Ind. 2006)

(Boehm, J.).
Habitual offender cocaine conviction appeal.

Conviction upheld. Dissent would reverse

habitual offender finding in part because

defendant appeared in prison orange to jury.

Attorney disbarment upheld. Dissent finds the

sanction too severe.

Tort liability, comparative negligence. Jury miscalculations did not require that liability not be imposed. Concurrence objects to the majority's urging trial judges to assist juries.

Murder, burglary, \& conspiracy to burglary; double jeopardy not violated, convictions upheld. Dissent would affirm first two but vacate conspiracy because sole overt act was the commission of the crime.

Medical malpractice, improper sterilization.

Preliminary determination that damages should not include the cost of raising a healthy child (reversing trial court and CA). Dissent 1 would apply Restatement $\S 920$; dissent 2 would include those costs.

Death sentence interlocutory appeal. Potential death sentence appropriate. Concurrence 1 would remand for sentencing with limitations on penalty; concurrence 2 would require the jury to find aggravating factors beyond a reasonable doubt.

Meth possession appeal. Various pieces of evidence were admissible. Concurrences with no opinions.

Adverse possession dispute. Claimants complied with all but tax requirements. Concurrence would overrule precedent and follow tax rule. If about courts' powers, then liberal.

Sexual misconduct with a minor; conviction upheld. Dissent would reverse conviction on weak proof of age.
CrimPro;

Conservative.

Sent'g/PR/Crim'l;

Conservative.

Tort; Conservative

CrimPro;

Conservative

Tort; Conservative.

CrimPro;

Conservative.

Dropped.

Other; Conservative.

CrimPro;

Conservative. 


\begin{tabular}{|c|c|c|}
\hline $\begin{array}{l}\text { David A. Ryker } \\
\text { Painting Co. v. } \\
\text { Nunamaker, } 849 \\
\text { N.E.2d } 1116 \text { (Ind. } \\
\text { 2006) (Dickson, J.). }\end{array}$ & $\begin{array}{l}\text { Underpayment of employee. Correction w/in } 14 \\
\text { days of Dep't of Labor determination cured error } \\
\text { and eliminated claim. Dissent would keep claim } \\
\text { alive. }\end{array}$ & Tort; Conservative. \\
\hline $\begin{array}{l}\text { Jackson v. State, } 868 \\
\text { N.E.2d } 494 \text { (Ind. 2007) } \\
\text { (Boehm, J.). }\end{array}$ & $\begin{array}{l}\text { Possession of cocaine with intent to deliver, no } \\
\text { errors, conviction upheld. Dissent finds defendant } \\
\text { did not properly waive the right to counsel. }\end{array}$ & $\begin{array}{l}\text { CrimPro; } \\
\text { Conservative. }\end{array}$ \\
\hline $\begin{array}{l}\text { In re Benkie, } 892 \\
\text { N.E.2d } 1237 \text { (Ind. } \\
\text { 2008) (per curiam). }\end{array}$ & $\begin{array}{l}\text { Reprimand of attorneys upheld. Concurrence } \\
\text { agrees except for violation of provision on ad } \\
\text { using data for predicting success. }\end{array}$ & $\begin{array}{l}\text { Sent'g/PR/Crim'l; } \\
\text { Conservative. }\end{array}$ \\
\hline $\begin{array}{l}\text { Bowles v. State, } 891 \\
\text { N.E.2d } 30 \text { (Ind. 2008) } \\
\text { (Boehm, J.). }\end{array}$ & $\begin{array}{l}\text { Cocaine dealing, motion to suppress. Evidence } \\
\text { was proper. Dissents would apply new rule } \\
\text { retroactively to the defendant's benefit and } \\
\text { exclude evidence. }\end{array}$ & $\begin{array}{l}\text { CrimPro; } \\
\text { Conservative. }\end{array}$ \\
\hline $\begin{array}{l}\text { State v. Jackson, } 889 \\
\text { N.E.2d } 819 \text { (Ind. 2008) } \\
\text { (Dickson, J.). }\end{array}$ & $\begin{array}{l}\text { Habitual traffic violator acquittal for lack of } \\
\text { specific knowledge for reason of license } \\
\text { revocation. State need not prove specific } \\
\text { knowledge. Dissent would require it as penalty } \\
\text { got much greater. }\end{array}$ & $\begin{array}{l}\text { Sent'g/PR/Crim'l; } \\
\text { Conservative. }\end{array}$ \\
\hline $\begin{array}{l}\text { Belvedere v. State, } 889 \\
\text { N.E.2d } 286 \text { (Ind. 2008) } \\
\text { (Boehm, J.). }\end{array}$ & $\begin{array}{l}\text { Drug trafficking conviction motion to suppress } \\
\text { defeated. Dissents would apply new } \\
\text { interpretation retroactively as in Membres v } \\
\text { State. }\end{array}$ & $\begin{array}{l}\text { CrimPro; } \\
\text { Conservative. }\end{array}$ \\
\hline $\begin{array}{l}\text { Membres v. State, } 889 \\
\text { N.E.2d } 265 \text { (Ind. 2008) } \\
\text { (Boehm, J.), reh'g } \\
\text { denied. }\end{array}$ & $\begin{array}{l}\text { Marijuana use, motion to suppress, evidence } \\
\text { admissible. Dissent would apply new } \\
\text { interpretation retroactively (as dissent in } \\
\text { Belvedere v State). }\end{array}$ & $\begin{array}{l}\text { CrimPro; } \\
\text { Conservative. }\end{array}$ \\
\hline $\begin{array}{l}\text { Villas W. II of } \\
\text { Willowridge } \\
\text { Homeowners Ass'n v. } \\
\text { McGlothin, } 885 \\
\text { N.E.2d } 1274 \text { (Ind. } \\
\text { 2008) (Shepard, C.J.), } \\
\text { cert. denied, } 129 \text { S. Ct. } \\
1527 \text { (2009). }\end{array}$ & $\begin{array}{l}\text { Homeownrs Ass'n v. Homeowner to uphold } \\
\text { prohibition on leasing, Fair Housing Act, } \\
\text { discrimination. Not necessarily discriminatory. } \\
\text { Dissent would uphold lower courts that found } \\
\text { covenant violated fair housing on disparate } \\
\text { impact grounds. }\end{array}$ & Other; Conservative. \\
\hline
\end{tabular}




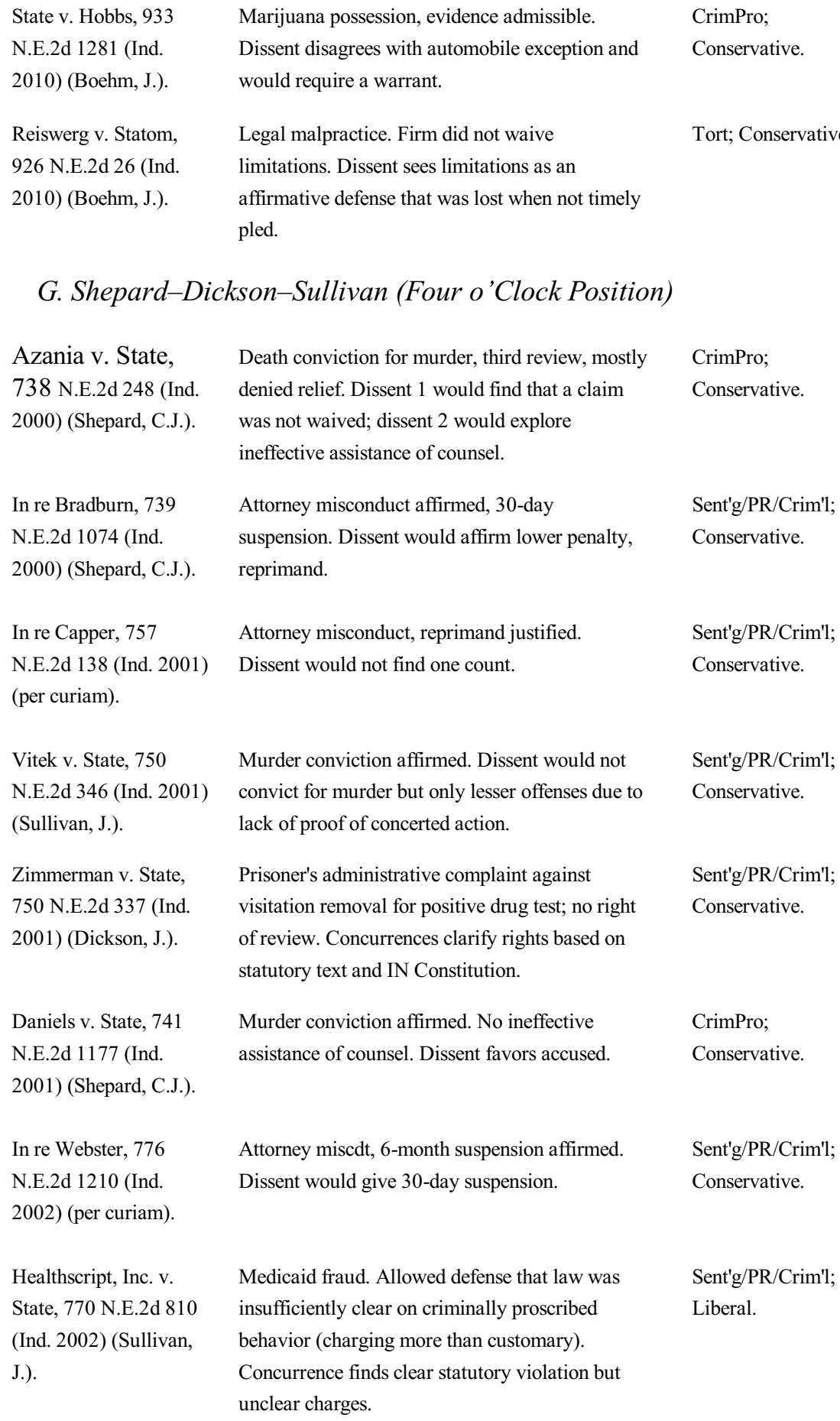

Azania v. State, 738 N.E.2d 248 (Ind. 2000) (Shepard, C.J.).

In re Bradburn, 739

N.E.2d 1074 (Ind.

2000) (Shepard, C.J.).

In re Capper, 757

N.E.2d 138 (Ind. 2001)

(per curiam).

Vitek v. State, 750

N.E.2d 346 (Ind. 2001)

(Sullivan, J.).

Zimmerman v. State, 750 N.E.2d 337 (Ind. 2001) (Dickson, J.).

Daniels v. State, 741

N.E.2d 1177 (Ind.

2001) (Shepard, C.J.).

In re Webster, 776

N.E.2d 1210 (Ind.

2002) (per curiam).

Healthscript, Inc. v.

State, 770 N.E. $2 \mathrm{~d} 810$

(Ind. 2002) (Sullivan,

J.).

Death conviction for murder, third review, mostly denied relief. Dissent 1 would find that a claim was not waived; dissent 2 would explore ineffective assistance of counsel.

Attorney misconduct affirmed, 30-day suspension. Dissent would affirm lower penalty, reprimand.

Attorney misconduct, reprimand justified.

Dissent would not find one count.

Murder conviction affirmed. Dissent would not convict for murder but only lesser offenses due to lack of proof of concerted action.

Prisoner's administrative complaint against visitation removal for positive drug test; no right of review. Concurrences clarify rights based on statutory text and IN Constitution.

Murder conviction affirmed. No ineffective assistance of counsel. Dissent favors accused.

Attorney miscdt, 6-month suspension affirmed. Dissent would give 30-day suspension.

Medicaid fraud. Allowed defense that law was insufficiently clear on criminally proscribed behavior (charging more than customary). Concurrence finds clear statutory violation but unclear charges.

CrimPro;

Conservative.

Sent'g/PR/Crim'l

Conservative.

Sent'g/PR/Crim'l;

Conservative.

Sent'g/PR/Crim'l;

Conservative.

Sent'g/PR/Crim'l;

Conservative.

CrimPro;

Conservative.

Sent'g/PR/Crim'l; Conservative.

Sent'g/PR/Crim'l; Liberal. 
INDIANA SUPREME COURT

\begin{tabular}{|c|c|c|}
\hline $\begin{array}{l}\text { Nw.Sch. Corp. v. } \\
\text { Linke, } 763 \text { N.E.2d } 972 \\
\text { (Ind. 2002) (Sullivan, } \\
\text { J.). }\end{array}$ & $\begin{array}{l}\text { Drug testing of students in various settings did } \\
\text { not violate IN const'n. Dissent would not have } \\
\text { tested. }\end{array}$ & Other; Conservative \\
\hline $\begin{array}{l}\text { Williams v. State, } 793 \\
\text { N.E.2d } 1019 \text { (Ind. } \\
\text { 2003) (Sullivan, J.). }\end{array}$ & $\begin{array}{l}\text { Death sentence, third review; alleged errors not } \\
\text { recognized, affirmed. Dissent would allow DNA } \\
\text { testing request. }\end{array}$ & $\begin{array}{l}\text { CrimPro; } \\
\text { Conservative. }\end{array}$ \\
\hline $\begin{array}{l}\text { Escobedo v. BHM } \\
\text { Health Assocs., } 818 \\
\text { N.E.2d } 930 \text { (Ind. 2004) } \\
\text { (Sullivan, J.). }\end{array}$ & $\begin{array}{l}\text { Affirmed refusal to pierce the corporate veil } \\
\text { against employee salary claims. Concurrence } \\
\text { affirms recognizing murky facts. }\end{array}$ & Dropped. \\
\hline $\begin{array}{l}\text { Helsley v. State, } 809 \\
\text { N.E.2d } 292 \text { (Ind. 2004) } \\
\text { (Dickson, J.). }\end{array}$ & $\begin{array}{l}\text { Double murder conviction upheld, no errors. } \\
\text { Concurrences would give stronger procedural } \\
\text { protection to defendant, allowing the judge not to } \\
\text { follow a jury recommendation of death. }\end{array}$ & $\begin{array}{l}\text { CrimPro; } \\
\text { Conservative. }\end{array}$ \\
\hline $\begin{array}{l}\text { Stroud v. State, } 809 \\
\text { N.E.2d } 274 \text { (Ind. 2004) } \\
\text { (Sullivan, J.). }\end{array}$ & $\begin{array}{l}\text { Affirms triple murder conviction, errors harmless, } \\
\text { vacates sentences on faulty jury instruction. } \\
\text { Concurrence states that trial court will have } \\
\text { latitude to override death recommendation if not } \\
\text { supported by the facts. }\end{array}$ & Dropped. \\
\hline $\begin{array}{l}\text { Baird v. State, } 833 \\
\text { N.E.2d } 28 \text { (Ind. 2005) } \\
\text { (Shepard, C.J.). }\end{array}$ & $\begin{array}{l}\text { Second postconviction review of triple murder } \\
\text { conviction that had two appellate reviews, not } \\
\text { granted. Dissent finds accused obviously insane. }\end{array}$ & $\begin{array}{l}\text { Sent'g/PR/Crim'l; } \\
\text { Conservative. }\end{array}$ \\
\hline $\begin{array}{l}\text { Blanck v. Ind. Dep't of } \\
\text { Corr., } 829 \text { N.E.2d } 505 \\
\text { (Ind. 2005) (Sullivan, } \\
\text { J.). }\end{array}$ & $\begin{array}{l}\text { Denies prisoner's private right of action against } \\
\text { disciplinary measures. Concurrence agrees with } \\
\text { no private right of action and would dismiss for } \\
\text { failure to state a claim. }\end{array}$ & Dropped. \\
\hline $\begin{array}{l}\text { Lambert v. State, } 825 \\
\text { N.E.2d } 1261 \text { (Ind. } \\
\text { 2005) (Shepard, C.J.). }\end{array}$ & $\begin{array}{l}\text { Leave for second postconviction relief petition } \\
\text { denied. Dissents would grant reconsideration } \\
\text { with strong doubts about the applicability of the } \\
\text { death penalty. }\end{array}$ & $\begin{array}{l}\text { Sent'g/PR/Crim'l; } \\
\text { Conservative. }\end{array}$ \\
\hline $\begin{array}{l}\text { State v. Azania, } 875 \\
\text { N.E.2d } 701 \text { (Ind. 2007) } \\
\text { (Sullivan, J.). }\end{array}$ & $\begin{array}{l}\text { Third death penalty resentencing did not time-bar } \\
\text { death sentence. Dissent would allow life without } \\
\text { parole. }\end{array}$ & $\begin{array}{l}\text { CrimPro; } \\
\text { Conservative. }\end{array}$ \\
\hline $\begin{array}{l}\text { State v. McManus, } 868 \\
\text { N.E.2d } 778 \text { (Ind. 2007) } \\
\text { (Shepard, C.J.). }\end{array}$ & $\begin{array}{l}\text { Denied death sentence reversal on retardation, } \\
\text { errors harmless. Dissent would affirm trial court's } \\
\text { retardation finding as not clearly erroneous. }\end{array}$ & $\begin{array}{l}\text { CrimPro; } \\
\text { Conservative. }\end{array}$ \\
\hline
\end{tabular}




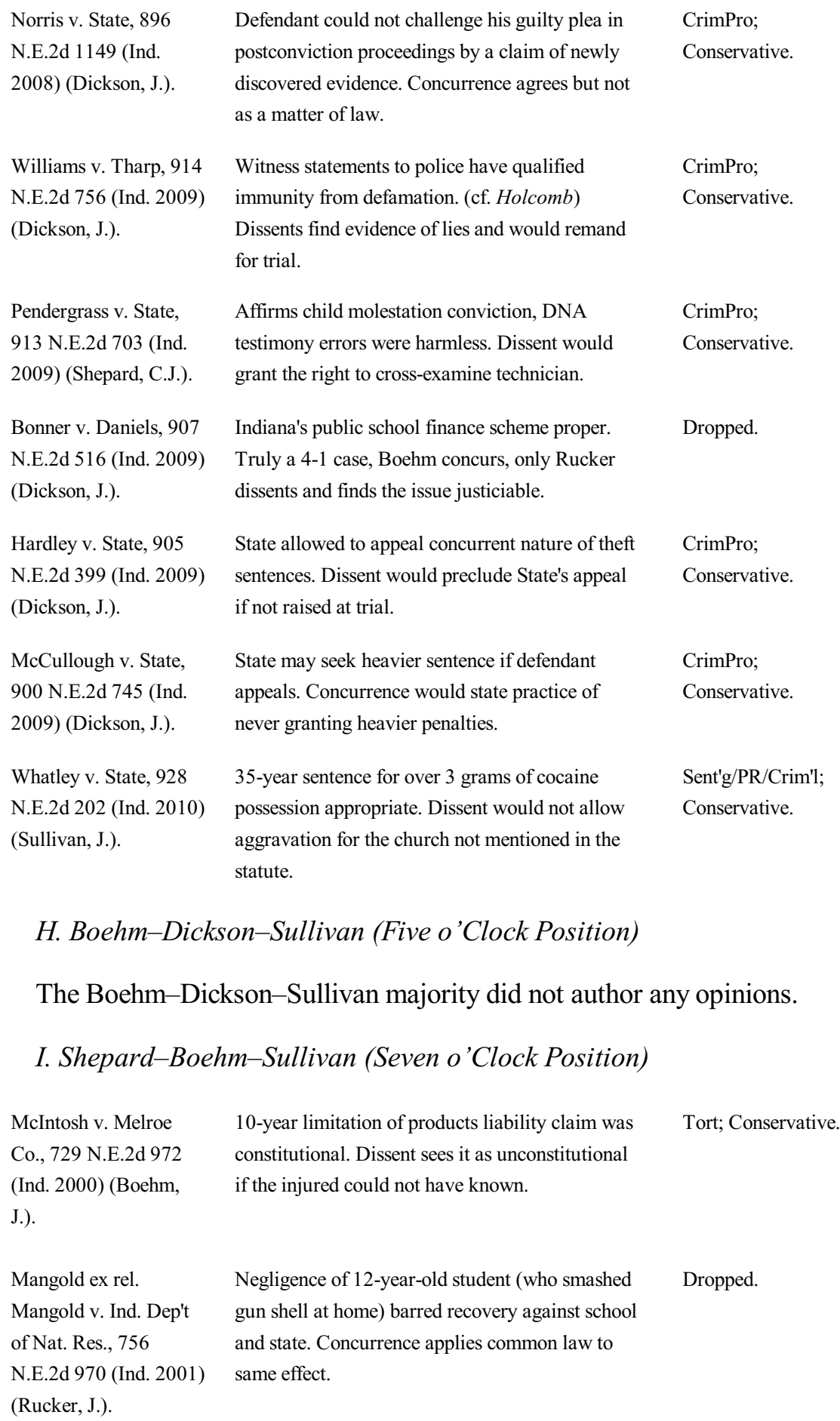

\section{H. Boehm-Dickson-Sullivan (Five o'Clock Position)}

\section{The Boehm-Dickson-Sullivan majority did not author any opinions.}

\section{Shepard-Boehm-Sullivan (Seven o'Clock Position)}


INDIANA SUPREME COURT

\author{
Hollowell v. State, 753 \\ Drug conviction appeal; affirmed, searches \\ CrimPro; \\ (Sullivan, J.). \\ permissible, prior battery conviction relevant. \\ Dissent would allow jury right not to find \\ habitual offender aggravation. \\ Fleetwood Enters., Inc. \\ Liability under Products Liability Act includes \\ harm to other products. Concurrence sees result \\ mandated by precedent. \\ Co., 749 N.E.2d 492 \\ (Ind. 2001) (Boehm, \\ J.). \\ Progressive Ins. Co. v. \\ Liability under Products Liability Act does not \\ Dropped. \\ Gen. Motors Corp. \\ accrue if damage only to the product. \\ 749 N.E.2d 484 (Ind. \\ Concurrence sees result mandated by precedent. \\ 2001) (Boehm, J.). \\ Durham ex rel. Estate \\ Wrongful death statute interpretation; no punitive \\ Tort; Conservative. \\ of Wade v. U-Haul \\ damages, loss of spousal consortium allowed. \\ Int'l, 745 N.E.2d 755 \\ Dissent would allow punitive damages. \\ (Ind. 2001) (Boehm, \\ J.). \\ In re Allen, 783 \\ Atty disciplinary imposition of 90-day \\ Dropped. \\ N.E.2d 1118 (Ind. \\ suspension proper. Dissent 1 finds it too lenient; \\ 2002) (per curiam). \\ dissent 2 too strict. \\ Turley v. Hyten, 772 \\ Landlord keeps security deposit of destructive \\ Other; Conservative. \\ N.E.2d 993 (Ind. 2002) \\ tenant. Dissent points out that statute requires LL \\ (Sullivan, J.) \\ to provide itemized damages w/in 45 days and \\ LL did not. \\ Ind. High Sch. Athletic \\ High school sports; appeal did not violate \\ Conservative. \\ Dropped. \\ Ass'n v. Martin, 765 \\ injunction. Appellate court (reversed) would have \\ N.E.2d 1238 (Ind. \\ allowed athlete to play. Dissent sides with \\ 2002) (Sullivan, J.). \\ appellate court. \\ Love v. State, 761 \\ Child molestation conviction upheld; errors \\ Dropped. \\ N.E.2d 806 (Ind. 2002) \\ harmless. Dissent concurs but would not allow a \\ (Sullivan, J.). \\ statement to reach the jury. \\ Springer v. State, 798 \\ Affirmed recklessness conviction; need not \\ CrimPro; \\ N.E.2d 431 (Ind. 2003) \\ instruct jury of lesser negligence for def's taking \\ (Sullivan, J.). \\ loaded cocked gun to avenge uninvited son's \\ expulsion from party. Dissent would require jury \\ to draw the line from negligence.
}




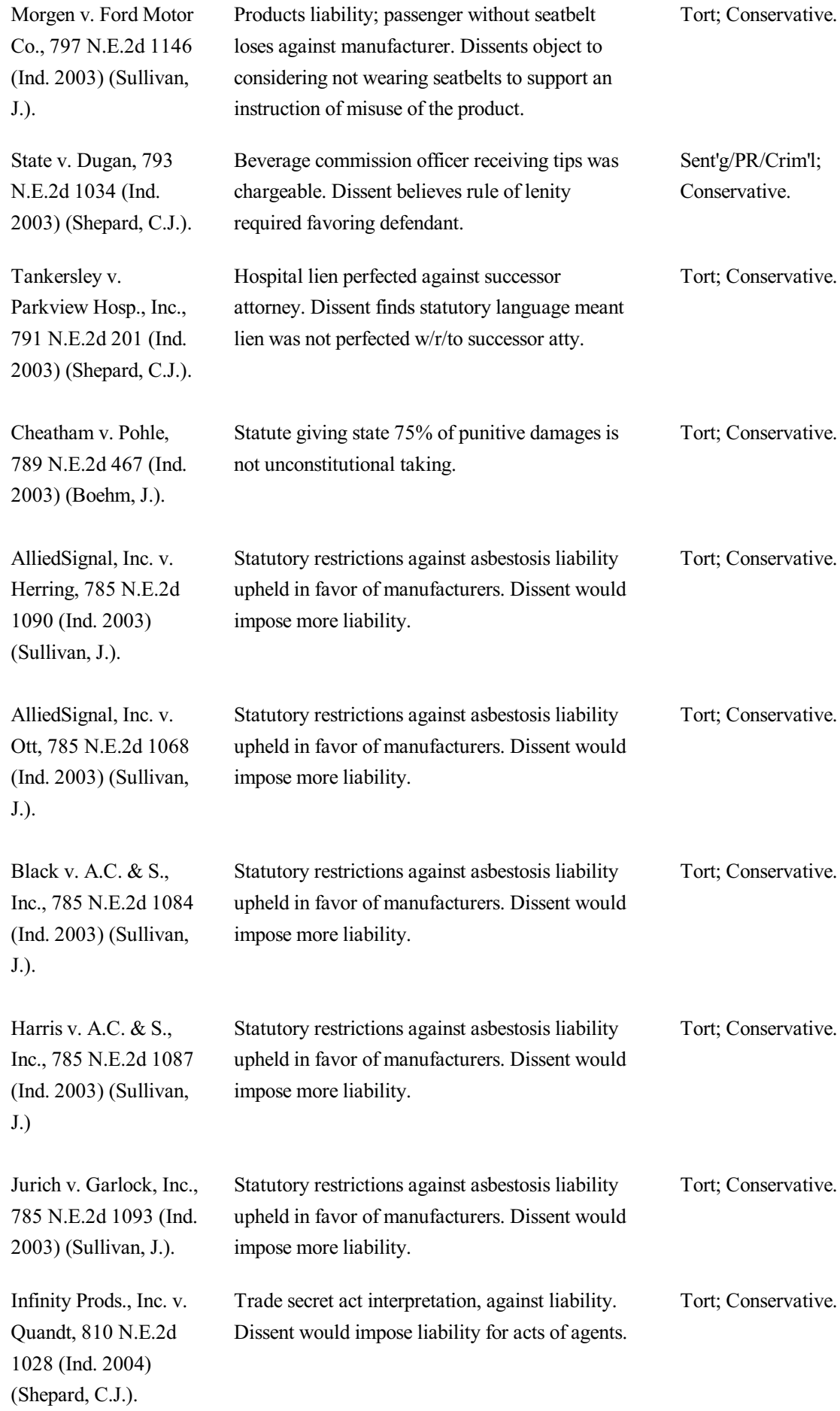

Morgen v. Ford Motor

Co., 797 N.E.2d 1146 (Ind. 2003) (Sullivan,

J.).

State v. Dugan, 793

N.E.2d 1034 (Ind.

2003) (Shepard, C.J.).

Tankersley v.

Parkview Hosp., Inc.,

791 N.E.2d 201 (Ind.

2003) (Shepard, C.J.).

Cheatham v. Pohle, 789 N.E.2d 467 (Ind.

2003) (Boehm, J.).

AlliedSignal, Inc. v.

Herring, 785 N.E.2d

1090 (Ind. 2003)

(Sullivan, J.).

AlliedSignal, Inc. v.

Ott, 785 N.E.2d 1068

(Ind. 2003) (Sullivan,

J.).

Black v. A.C. \& S., Inc., 785 N.E.2d 1084 (Ind. 2003) (Sullivan, J.).

Harris v. A.C. \& S., Inc., 785 N.E. $2 \mathrm{~d} 1087$ (Ind. 2003) (Sullivan, J.)

Jurich v. Garlock, Inc., 785 N.E.2d 1093 (Ind. 2003) (Sullivan, J.).

Infinity Prods., Inc. v. Quandt, 810 N.E.2d 1028 (Ind. 2004)

(Shepard, C.J.).

Products liability; passenger without seatbelt loses against manufacturer. Dissents object to considering not wearing seatbelts to support an instruction of misuse of the product.

Beverage commission officer receiving tips was chargeable. Dissent believes rule of lenity required favoring defendant.

Hospital lien perfected against successor attorney. Dissent finds statutory language meant lien was not perfected $\mathrm{w} / \mathrm{r} /$ to successor atty.

Statute giving state $75 \%$ of punitive damages is not unconstitutional taking.

Statutory restrictions against asbestosis liability upheld in favor of manufacturers. Dissent would impose more liability.

Statutory restrictions against asbestosis liability upheld in favor of manufacturers. Dissent would impose more liability.

Statutory restrictions against asbestosis liability upheld in favor of manufacturers. Dissent would impose more liability.

Statutory restrictions against asbestosis liability upheld in favor of manufacturers. Dissent would impose more liability.

Statutory restrictions against asbestosis liability upheld in favor of manufacturers. Dissent would impose more liability.

Trade secret act interpretation, against liability. Dissent would impose liability for acts of agents.

Tort; Conservative.

Sent'g/PR/Crim'l;

Conservative.

Tort; Conservative.

Tort; Conservative.

Tort; Conservative

Tort; Conservative

Tort; Conservative

Tort; Conservative

Tort; Conservative.

Tort; Conservative 


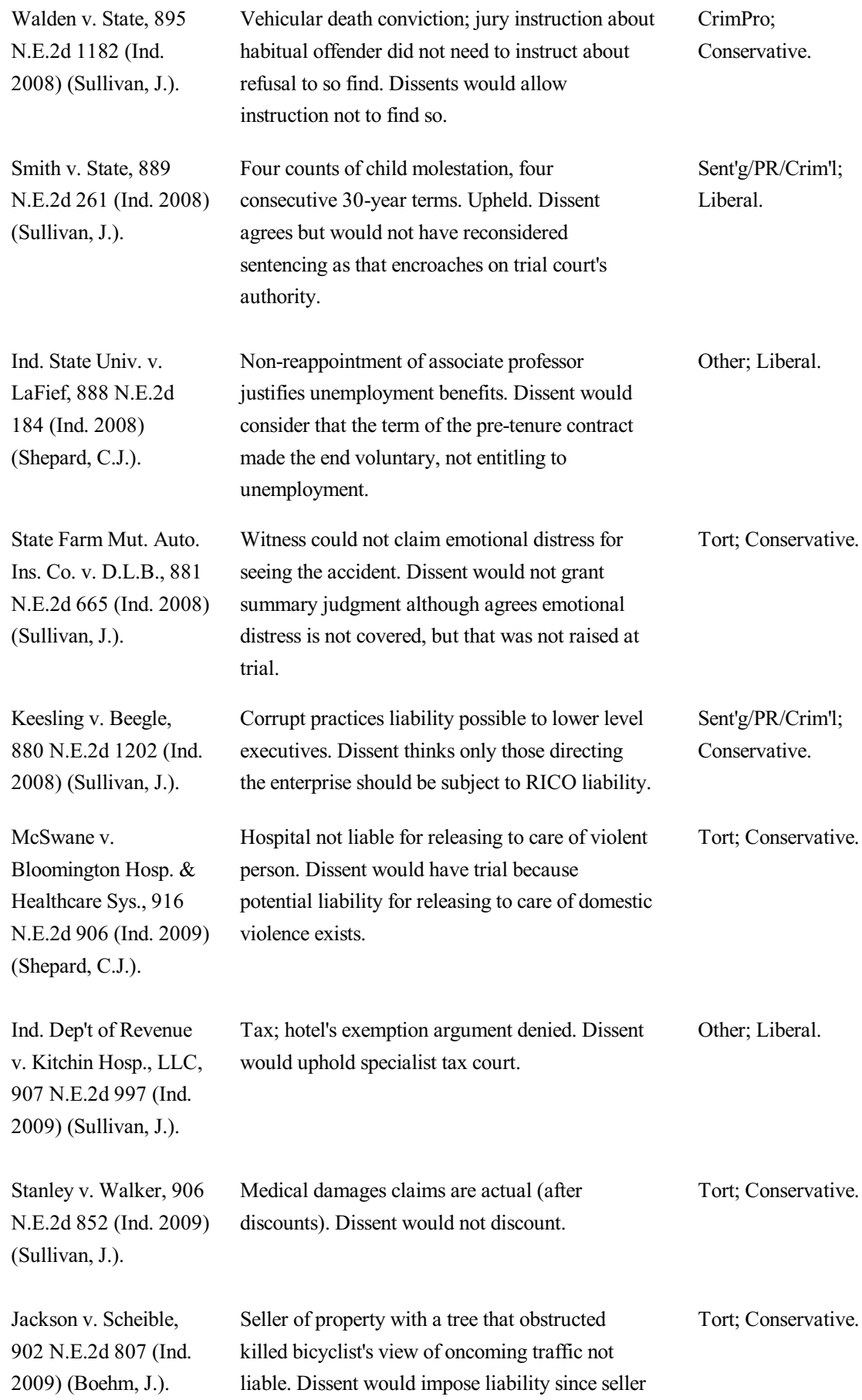

consecutive 30-year terms. Upheld. Dissent

agrees but would not have reconsidered

sentencing as that encroaches on trial court's authority.

Ind. State Univ. v.

Non-reappointment of associate professor

Conservative.

LaFief, 888 N.E.2d

184 (Ind. 2008)

(Shepard, C.J.).

justifies unemployment benefits. Dissent would

consider that the term of the pre-tenure contract

made the end voluntary, not entitling to

unemployment.

State Farm Mut. Auto.

Witness could not claim emotional distress for

Ins. Co. v. D.L.B., 881

seeing the accident. Dissent would not grant

N.E.2d 665 (Ind. 2008)

(Sullivan, J.).

summary judgment although agrees emotional

distress is not covered, but that was not raised at trial.

Keesling v. Beegle, 880 N.E.2d 1202 (Ind.

2008) (Sullivan, J.).

Corrupt practices liability possible to lower level

Sent'g/PR/Crim'l; executives. Dissent thinks only those directing the enterprise should be subject to RICO liability.

Conservative.

McSwane v.

Hospital not liable for releasing to care of violent

Bloomington Hosp. \&

person. Dissent would have trial because

Healthcare Sys., 916

potential liability for releasing to care of domestic

N.E.2d 906 (Ind. 2009)

(Shepard, C.J.).

Ind. Dep't of Revenue

Tax; hotel's exemption argument denied. Dissent

Other; Liberal.

v. Kitchin Hosp., LLC, would uphold specialist tax court.

907 N.E.2d 997 (Ind.

2009) (Sullivan, J.).

Stanley v. Walker, 906

Medical damages claims are actual (after

N.E.2d 852 (Ind. 2009)

discounts). Dissent would not discount.

(Sullivan, J.).

Jackson v. Scheible, 902 N.E.2d 807 (Ind.

Seller of property with a tree that obstructed killed bicyclist's view of oncoming traffic not 2009) (Boehm, J.).

Sent'g/PR/Crim'l;

Liberal.

Other; Liberal.

Tort; Conservative.

Tort; Conservative.

Tort; Conservative.

Tort; Conservative. 

INDIANA SUPREME COURT

\begin{tabular}{|c|c|c|}
\hline $\begin{array}{l}\text { State v. Kimco of } \\
\text { Evansville, Inc., } 902 \\
\text { N.E.2d } 206 \text { (Ind. 2009) } \\
\text { (Boehm, J.). }\end{array}$ & $\begin{array}{l}\text { Reconfiguration of roads through shopping center } \\
\text { was not a compensable taking. Dissent would } \\
\text { affirm lower cts that found taking. }\end{array}$ & Other; Conservative. \\
\hline $\begin{array}{l}\text { In re Lauter, } 933 \\
\text { N.E.2d } 1258 \text { (Ind. } \\
\text { 2010) (per curiam). }\end{array}$ & $\begin{array}{l}\text { Reversed lower court and imposed reprimand on } \\
\text { attorney. Dissent considered proof insufficient } \\
\text { and would not sanction. }\end{array}$ & $\begin{array}{l}\text { Sent'g/PR/Crim'l; } \\
\text { Conservative. }\end{array}$ \\
\hline $\begin{array}{l}\text { Vaughn v. Daniels Co. } \\
\text {, } 841 \text { N.E.2d } 1133 \\
\text { (Ind. 2006) (Boehm, } \\
\text { J.). }\end{array}$ & $\begin{array}{l}\text { Worker v mine; mostly against liability of mine. } \\
\text { Dissent would allow worker to recover under } \\
\text { products liability as "user" or "consumer." }\end{array}$ & Tort; Conservative. \\
\hline \multicolumn{3}{|c|}{ J. Shepard-Rucker-Sullivan (Eight o'Clock Position) } \\
\hline $\begin{array}{l}\text { Allen v. State, } 720 \\
\text { N.E.2d } 707 \text { (Ind. 1999) } \\
\text { (Shepard, C.J.). }\end{array}$ & $\begin{array}{l}\text { Reduction of } 165 \text {-year sentence to } 115 \text { for murder } \\
\text { was not unreasonable. Dissents would uphold on } \\
\text { finding jury instruction appropriate. }\end{array}$ & $\begin{array}{l}\text { Sent'g/PR/Crim'l; } \\
\text { Liberal. }\end{array}$ \\
\hline $\begin{array}{l}\text { Oman v. State, } 737 \\
\text { N.E.2d } 1131 \text { (Ind. } \\
\text { 2000) (Sullivan, J.). }\end{array}$ & $\begin{array}{l}\text { Firefighter; driving under the influence inferred } \\
\text { from mandated test. Admissible. Concurrence } \\
\text { would impose some confidentiality on tests. }\end{array}$ & $\begin{array}{l}\text { CrimPro; } \\
\text { Conservative. }\end{array}$ \\
\hline $\begin{array}{l}\text { Ellis v. State, } 736 \\
\text { N.E.2d } 731 \text { (Ind. 2000) } \\
\text { (Shepard, C.J.). }\end{array}$ & $\begin{array}{l}\text { Ordering resentencing of } 165 \text {-year multiple } \\
\text { murder sentence. Dissent does not find } \\
\text { consecutive sentences an error. }\end{array}$ & $\begin{array}{l}\text { Sent'g/PR/Crim'l; } \\
\text { Liberal. }\end{array}$ \\
\hline $\begin{array}{l}\text { City of Gary v. Ind. } \\
\text { Bell Tel. Co., } 732 \\
\text { N.E.2d } 149 \text { (Ind. 2000) } \\
\text { (Sullivan, J.), reh'g } \\
\text { denied. }\end{array}$ & $\begin{array}{l}\text { Upholds city right to impose fee/tax on use of its } \\
\text { property by telco. Dissent disagrees for the period } \\
\text { before the passage of corresponding law. }\end{array}$ & Other; Liberal. \\
\hline $\begin{array}{l}\text { Midwest Sec. Life Ins. } \\
\text { Co. v. Stroup, } 730 \\
\text { N.E.2d } 163 \text { (Ind. 2000) } \\
\text { (Shepard, C.J.). }\end{array}$ & $\begin{array}{l}\text { ERISA preempts common law breach claims. } \\
\text { Concurrence would preserve jury trials that } \\
\text { appellate opinion precluded. }\end{array}$ & Tort; Conservative. \\
\hline $\begin{array}{l}\text { Francis v. State, } 758 \\
\text { N.E.2d } 528 \text { (Ind. 2001) } \\
\text { (Rucker, J.). }\end{array}$ & $\begin{array}{l}\text { Murder conviction; errors were harmless but } \\
\text { vacates lesser included robberies. Dissent would } \\
\text { uphold lesser robberies. }\end{array}$ & $\begin{array}{l}\text { Sent'g/PR/Crim'l; } \\
\text { Liberal. }\end{array}$ \\
\hline
\end{tabular}




\begin{tabular}{|c|c|c|}
\hline $\begin{array}{l}\text { Randolph v. State, } 755 \\
\text { N.E.2d } 572 \text { (Ind. 2001) } \\
\text { (Rucker, J.). }\end{array}$ & $\begin{array}{l}\text { Murder conviction; no self-defense, no mistrial } \\
\text { because court told the defense that it could } \\
\text { admonish the jury about lack of criminal record. } \\
\text { The dissent finds admonition refusal a waiver } \\
\text { only if admonition would have cured error. }\end{array}$ & $\begin{array}{l}\text { Sent'g/PR/Crim'l; } \\
\text { Conservative. }\end{array}$ \\
\hline $\begin{array}{l}\text { Miller v. State, } 753 \\
\text { N.E.2d } 1284 \text { (Ind. } \\
\text { 2001) (Sullivan, J.), } \\
\text { reh'g denied. }\end{array}$ & $\begin{array}{l}\text { Robbery and multiple side crimes; no errors. } \\
\text { Concurrence would grant greater procedural } \\
\text { protection of the right to object. }\end{array}$ & $\begin{array}{l}\text { CrimPro; } \\
\text { Conservative. }\end{array}$ \\
\hline $\begin{array}{l}\text { Wallace v. State, } 753 \\
\text { N.E.2d } 568 \text { (Ind. 2001) } \\
\text { (Rucker, J.). }\end{array}$ & $\begin{array}{l}\text { Child molestation prosecutions were time-barred. } \\
\text { Dissent finds limitations to be waivable, requiring } \\
\text { an objection. }\end{array}$ & $\begin{array}{l}\text { Sent'g/PR/Crim'l; } \\
\text { Liberal. }\end{array}$ \\
\hline $\begin{array}{l}\text { Wadsworth v. State, } \\
750 \text { N.E.2d } 774 \text { (Ind. } \\
\text { 2001) (Shepard, C.J.), } \\
\text { reh'g denied. }\end{array}$ & $\begin{array}{l}\text { Murder, burglary convictions proper. Dissent } \\
\text { might doubt the sufficiency of burglary evidence } \\
\text { (no opinion). }\end{array}$ & $\begin{array}{l}\text { Sent'g/PR/Crim'l; } \\
\text { Conservative. }\end{array}$ \\
\hline $\begin{array}{l}\text { Holsinger v. State, } 750 \\
\text { N.E.2d } 354 \text { (Ind. 2001) } \\
\text { (Sullivan, J.). }\end{array}$ & $\begin{array}{l}\text { Double murder, robberies; convictions proper, } \\
\text { sentences should be concurrent. Dissent } 1 \text { : } \\
\text { failure to request an admonishment does not } \\
\text { necessarily result in waiver; would uphold } \\
\text { consecutive nature of sentences. Dissent } 2 \text { agrees } \\
\text { errors were harmless but more important than } \\
\text { majority see them. Not considered } 3-2 \text { because } \\
\text { only one true dissent, and that is from sentencing, } \\
\text { dissents also have liberal nature in the CrimPro } \\
\text { issues, but again each on a different one. }\end{array}$ & Dropped. \\
\hline $\begin{array}{l}\text { Pennycuff v. State, } \\
745 \text { N.E.2d } 804 \text { (Ind. } \\
\text { 2001) (Shepard, C.J.). }\end{array}$ & $\begin{array}{l}\text { Child molestation and sexual misconduct with } \\
\text { minor convictions proper; proper procedure for } \\
\text { no mitigation for cooperation and search proper. } \\
\text { Dissents would reverse. }\end{array}$ & $\begin{array}{l}\text { CrimPro; } \\
\text { Conservative. }\end{array}$ \\
\hline $\begin{array}{l}\text { Noble County v. } \\
\text { Rogers, } 745 \text { N.E.2d } \\
194 \text { (Ind. 2001) }\end{array}$ & $\begin{array}{l}\text { Landowner's counterclaim against county for } \\
\text { falsely not granting license was properly barred. } \\
\text { Dissent would allow counterclaim. }\end{array}$ & Other; Liberal. \\
\hline
\end{tabular}

(Sullivan, J.). 
Guyton v. State, 771

N.E.2d 1141 (Ind.

2002) (Shepard, C.J.).

State v. Adams, 762

N.E.2d 728 (Ind. 2002)

(Sullivan, J.), reh'g

denied, cert denied,

537 U.S. 1030 (2002).

Kennedy v. Guess Inc., 806 N.E.2d 776 (Ind.

2004) (Shepard, C.J.),

reh'g denied.

Fackler v. Powell, 839

N.E.2d 165 (Ind. 2005)

(Sullivan, J.).

Clinic for Women, Inc.

v. Brizzi, 837 N.E.2d

973 (Ind. 2005)

(Rucker, J.).

Cotto v. State, 829

N.E.2d 520 (Ind. 2005)

(Rucker, J.).

State v. Spillers, 847

N.E.2d 949 (Ind. 2006)

(Rucker, J.).

State Farm Mut. Auto.

Ins. Co. v. Estep, 873

N.E.2d 1021 (Ind.

2007) (Shepard, C.J.).
Murder and side crimes; attempted murder

instruction ought to include specific intent to kill.

Concurrences stricter, to find double jeopardy for lesser crime, the def must show "reasonable, not speculative or remote," possibility that the jury used the same evidentiary facts.

Improperly found cocaine can still be taxed.

Dissent sees the same justification of the exclusionary rule operating here and would not allow state to benefit by taxing for its violation.

Products liability for broken umbrella; mostly reverses summary judgment in favor of defendants. Concurrence would grant SJ to licensor, Guess.

Enforcing mrtge assigned by dissolution; dissolution court retains jurisdiction to interpret decree. Dissent would assign dispute to the local court.

Statute requiring $18 \mathrm{hr}$ abortion notice not unconstitutional. Dissent 1 (framed as "concurrence in result") would dismiss; dissent 2 would find right to liberty. Unorthodox as dissents on either side of majority.

50-year sentence for meth possession shortened to 30 . Dissent would uphold trial court's sentencing.

Motion to suppress drug evidence; officer's good faith belief in warrant allowed it. Concurrence would allow search without good faith, as a statement against interest.

Auto accident; assigning claims to lawyers; impermissible; insurance co may intervene. Dissent: insurance co may not intervene and order of assignment of claim was permissible.
Sent'g/PR/Crim'l;

Liberal.

Other; Liberal.

Tort; Liberal

Other; Conservative.

Dropped

Sent'g/PR/Crim'l;

Liberal.

CrimPro; Liberal.

Tort; Conservative 
Grant v. Hager, 868

N.E.2d 801 (Ind. 2007)

(Sullivan, J.).

Sweatt v. State, 887

N.E.2d 81 (Ind. 2008)

(Shepard, C.J.)

Auto-Owners Ins. Co

v. Bank One, 879

N.E.2d 1086 (Ind.

2008) (Sullivan, J.).

Jensen v. State, 905

N.E.2d 384 (Ind. 2009)

(Rucker, J.).

Ind. Dep't of State

Revenue v. Belterra

Resort Ind., LLC, 935

N.E.2d 174 (Ind. 2010)

(Rucker, J.), reh'g

granted, 942 N.E.2d

796 (Ind. 2011).

Caesars Riverboat

Casino, LLC v

Kephart, 934 N.E.2d

1120 (Ind. 2010)

(Rucker, J.).

Knight v. State, 930

N.E.2d 20 (Ind. 2010)

(Rucker, J.).

St. Joseph Cty.

Comm'rs v. Nemeth, 929 N.E.2d 703 (Ind

2010) (Sullivan, J.).
Appropriate for trial court to overcome

presumption and order custodial parent to pay support to noncustodial. Dissent would uphold court that followed guidelines.

Burglary enhanced; enhancement from two counts of prior offense not impermissible, consecutive sentences impermissible. Dissent would allow consecutive sentences.

Insurance co claimed bank's acceptance of fraudulent checks by employee of bank was conversion; no liability of bank. Dissent agrees but would allow trial.

Sex offender by plea bargain had to submit to subsequent lifetime registration. Dissent 1 would find claims not yet ripe for adjudication; dissent 2 would prevent additional registration obligation as ex post facto punishment.

Acquisition of riverboat casino subject to sales tax as retail transaction. Dissent sees it as a capital contribution, not taxed

Gambler defense of abuse of compulsive gambling disease barred by statute. Dissent 1 concurs but would limit framework of liability generally; dissent 2 would allow liability. Unorthodox 3-2 as dissents on either side of majority.

Multiple burglars who got 70 years after State revoked 30-year plea, should have sentence shortened. Dissent without opinion.

Dispute btwn county and probate court; approves cost-cutting renovations, denies salary increases, remands on land sale. Dissent concurs in all except land sale, would affirm lower court which vacated mandate not to sell w/out court's consent.
Other; Conservative.

Sent'g/PR/Crim'l;

Liberal.

Tort; Conservative

Sent'g/PR/Crim'l;

Conservative.

Other; Liberal.

Dropped.

Sent'g/PR/Crim'l;

Liberal.

Other; Conservative. 